\title{
Inverse modeling of pan-Arctic methane emissions at high spatial resolution: what can we learn from assimilating satellite retrievals and using different process-based wetland and lake biogeochemical models?
}

\author{
Zeli Tan ${ }^{1,2}$, Qianlai Zhuang ${ }^{1,2,3}$, Daven K. Henze ${ }^{4}$, Christian Frankenberg ${ }^{5}$, Ed Dlugokencky ${ }^{6}$, Colm Sweeney $^{6}$, \\ Alexander J. Turner ${ }^{7}$, Motoki Sasakawa ${ }^{8}$, and Toshinobu Machida ${ }^{8}$ \\ ${ }^{1}$ Department of Earth, Atmospheric, and Planetary Sciences, Purdue University, West Lafayette, Indiana, USA \\ ${ }^{2}$ Purdue Climate Change Research Center, Purdue University, West Lafayette, Indiana, USA \\ ${ }^{3}$ Department of Agronomy, Purdue University, West Lafayette, Indiana, USA \\ ${ }^{4}$ Department of Mechanical Engineering, University of Colorado, Boulder, Colorado, USA \\ ${ }^{5}$ Jet Propulsion Laboratory/California Institute of Technology, Pasadena, California, USA \\ ${ }^{6}$ Global Monitoring Division, NOAA Earth System Research Laboratory, Boulder, Colorado, USA \\ ${ }^{7}$ School of Engineering and Applied Sciences, Harvard University, Cambridge, Massachusetts, USA \\ ${ }^{8}$ National Institute for Environmental Studies, Tsukuba, Japan \\ Correspondence to: Qianlai Zhuang (qzhuang@purdue.edu)
}

Received: 19 October 2015 - Published in Atmos. Chem. Phys. Discuss.: 18 November 2015

Revised: 15 September 2016 - Accepted: 25 September 2016 - Published: 12 October 2016

\begin{abstract}
Understanding methane emissions from the Arctic, a fast-warming carbon reservoir, is important for projecting future changes in the global methane cycle. Here we optimized methane emissions from north of $60^{\circ} \mathrm{N}$ (pan-Arctic) regions using a nested-grid high-resolution inverse model that assimilates both high-precision surface measurements and column-average SCanning Imaging Absorption spectroMeter for Atmospheric CHartogrphY (SCIAMACHY) satellite retrievals of methane mole fraction. For the first time, methane emissions from lakes were integrated into an atmospheric transport and inversion estimate, together with prior wetland emissions estimated with six biogeochemical models. In our estimates, in 2005, global methane emissions were in the range of 496.4-511.5 $\mathrm{Tg} \mathrm{yr}^{-1}$, and pan-Arctic methane emissions were in the range of $11.9-28.5 \mathrm{Tg} \mathrm{yr}^{-1}$. Methane emissions from pan-Arctic wetlands and lakes were 5.5-14.2 and 2.4-14.2 $\mathrm{Tg} \mathrm{yr}^{-1}$, respectively. Methane emissions from Siberian wetlands and lakes are the largest and also have the largest uncertainty. Our results indicate that the uncertainty introduced by different wetland models could be much larger than the uncertainty of each inversion. We also show that assimilating satellite retrievals can reduce the un-
\end{abstract}

certainty of the nested-grid inversions. The significance of lake emissions cannot be identified across the pan-Arctic by high-resolution inversions, but it is possible to identify high lake emissions from some specific regions. In contrast to global inversions, high-resolution nested-grid inversions perform better in estimating near-surface methane concentrations.

\section{Introduction}

Methane $\left(\mathrm{CH}_{4}\right)$ is the second-most-powerful carbon-based greenhouse gas in the atmosphere behind carbon dioxide $\left(\mathrm{CO}_{2}\right)$ and also plays a significant role in the cycles of ozone, hydroxyl radicals $(\mathrm{OH})$, and stratospheric water vapor (Myhre et al., 2013; Shindell et al., 2009). The atmospheric burden of $\mathrm{CH}_{4}$ is now more than factor of 2.5 greater than the preindustrial value of about 700 ppb (Etheridge et al., 1998), mainly due to anthropogenic emissions. Major sources and sinks of $\mathrm{CH}_{4}$ have been identified (Denman et al., 2007); however their quantification is still of large uncertainties, and the annual and interannual variability of atmospheric $\mathrm{CH}_{4}$ 
are not well explained. For instance, scientists have not yet agreed on what caused the leveling-off of atmospheric $\mathrm{CH}_{4}$ since the 1980s (Dlugokencky et al., 2003; Bousquet et al., 2006; Aydin et al., 2011; Kai et al., 2011; Levin et al., 2012; Simpson et al., 2012; Kirschke et al., 2013) and the recent rebounding of its growth since 2007 (Rigby et al., 2008; Dlugokencky et al., 2009; Nisbet et al., 2014).

To reduce the quantification uncertainty of $\mathrm{CH}_{4}$ sources and sinks, much effort has been made using Bayesian inference (Bergamaschi et al., 2007, 2009, 2013; Meirink et al., 2008; Cressot et al., 2014; Houweling et al., 2014; Alexe et al., 2015). In these studies, in situ and/or satellite observations of $\mathrm{CH}_{4}$ that are representative of large spatial scales were assimilated into a chemical transport model (CTM) to constrain the initial estimates of $\mathrm{CH}_{4}$ sources and sinks that are inventoried from field studies, industrial investigations, and biogeochemical models (Fung et al., 1991; Zhuang et al., 2004; Walter et al., 2006; Zhu et al., 2013; Tan and Zhuang, 2015a, b). Spaceborne observations of atmospheric $\mathrm{CH}_{4}$ are especially useful in inverse modeling because they can deliver dense and continuous coverage unachievable by surface networks or aircraft campaigns (Bergamaschi et al., 2007). There are two types of nadir satellite $\mathrm{CH}_{4}$ retrievals: one from solar backscatter in the shortwave infrared (SWIR) and the other from thermal infrared radiation (TIR). Between them, SWIR retrievals have been more widely used in atmospheric inversion of $\mathrm{CH}_{4}$ emissions (Bergamaschi et al., 2007, 2009, 2013; Fraser et al., 2013; Cressot et al., 2014; Houweling et al., 2014; Monteil et al., 2014; Wecht et al., 2014; Alexe et al., 2015; Turner et al., 2015) because they can provide column concentrations with near-uniform vertical sensitivity down to the surface. To date, most of the inversions have been operated at coarse spatial resolutions over $300 \mathrm{~km}$. However, partly owing to their coarse resolutions, it is impossible for these inversions to constrain different $\mathrm{CH}_{4}$ sources that are spatially colocated (Fung et al., 1991; Wecht et al., 2014). To address this issue, regional inverse models at fine spatial resolutions were developed (Miller et al., 2013; Wecht et al., 2014; Thompson et al., 2015). For example, Wecht et al. (2014) and Turner et al. (2015) have used the $1 / 2^{\circ} \times 2 / 3^{\circ}$ horizontal resolution Goddard Earth Observing System-Chemistry (GEOS-Chem) adjoint model to constrain $\mathrm{CH}_{4}$ emissions over North America.

Estimating $\mathrm{CH}_{4}$ emissions from the Arctic is important for understanding the global carbon cycle because the fast warming of Arctic permafrost, one of the largest organic carbon reservoirs (Tarnocai et al., 2009), could lead to a rapid rise of $\mathrm{CH}_{4}$ emissions (Zhuang et al., 2006; Walter et al., 2007; Koven et al., 2011). Natural sources dominate the Arctic $\mathrm{CH}_{4}$ inventory (Fisher et al., 2011), e.g., wetlands (McGuire et al., 2012), lakes (Walter et al., 2006; Bastviken et al., 2011), sea shelves (Berchet et al., 2016; Myhre et al., 2016), and oceans (Kort et al., 2012). As the factors governing natural $\mathrm{CH}_{4}$ production (methanogenesis) and oxidation (methanotrophy) are notoriously heterogeneous, estimates of Arctic $\mathrm{CH}_{4}$ emis- sions are still poorly constrained, even with decades of sitelevel and modeling studies (Zhuang et al., 2004; Bastviken et al., 2011; Schuur et al., 2015; Tan and Zhuang, 2015a, b). Previous $\mathrm{CH}_{4}$ inversions over the Arctic only assimilated surface measurements that were too sparse to constrain finescale $\mathrm{CH}_{4}$ fluxes. Also, possibly important $\mathrm{CH}_{4}$ sources that were newly identified, e.g., $\mathrm{CH}_{4}$ emissions from Arctic lakes (Walter et al., 2006, 2007; Bastviken et al., 2011; Tan and Zhuang, 2015a) and the East Siberian Shelf (Berchet et al., 2016; Thornton et al., 2016), have not been included in these studies. Given the ill-posed nature of trace-gas inversions, realistic prior fluxes could be important for successful inverse modeling of $\mathrm{CH}_{4}$ emissions from the Arctic (Kaminski and Heimann, 2001).

To address these issues, we used the adjoint of a 3-D CTM at a high spatial resolution (less than $60 \mathrm{~km}$ ) to improve the quantification of pan-Arctic $\mathrm{CH}_{4}$ emissions in 2005. We explored the feasibility of using satellite $\mathrm{CH}_{4}$ retrievals overpassing the pan-Arctic to further constrain regional $\mathrm{CH}_{4}$ emissions. For the first time, $\mathrm{CH}_{4}$ emissions from pan-Arctic lakes were included in high-resolution inverse modeling of $\mathrm{CH}_{4}$ emissions. As wetland emissions are likely the largest pan-Arctic $\mathrm{CH}_{4}$ source, we also investigated the sensitivity of our estimates to the use of different wetland emission scenarios. Section 2 describes the observation data of atmospheric $\mathrm{CH}_{4}$ that were used to infer $\mathrm{CH}_{4}$ emissions and evaluate posterior estimates. Section 3 details the wetland and lake biogeochemical models that were used in this study (Sect. 3.1), the pan-Arctic nested-grid CTM (Sect. 3.2), and the adjointbased inversion method (Sect. 3.3). Section 4 presents the posterior $\mathrm{CH}_{4}$ emissions, their evaluation and further discussion.

\section{Observations}

\subsection{Satellite retrievals}

SWIR $\mathrm{CH}_{4}$ retrievals are available from SCanning Imaging Absorption spectroMeter for Atmospheric CHartogrphY (SCIAMACHY) for 2003-2012 (Frankenberg et al., 2006, 2008, 2011) and Greenhouse Gases Observing SATellite (GOSAT) for 2009 to present (Parker et al., 2011). SCIAMACHY, aboard the European Space Agency's environmental research satellite Envisat, retrieves column-averaged $\mathrm{CH}_{4}$ mixing ratios $\left(\mathrm{XCH}_{4}\right)$ from the SWIR nadir spectra (channel 6: $1.66-1.67 \mu \mathrm{m})$ using the iterative maximum a posteriori differential optical absorption spectroscopy (IMAP-DOAS) algorithm (Frankenberg et al., 2006, 2008, 2011). The satellite operates in a near-polar, sun-synchronous orbit at an altitude of $800 \mathrm{~km}$. At channel 6, the ground pixel size of the retrievals is about $30 \mathrm{~km}$ (along-track) $\times 60 \mathrm{~km}$ (across-track). We use version 6.0 proxy $\mathrm{CH}_{4}$ retrievals from Frankenberg et al. (2011) that provide a weighted column-average dry-mole fraction of $\mathrm{CH}_{4}$ with 10-layer averaging kernels and prior 
$\mathrm{CH}_{4}$ profiles. The averaging kernels show near-uniform vertical sensitivity in the troposphere and declining sensitivity above the tropopause (Butz et al., 2010). Some auxiliary data - e.g., the air mass factor $A_{\mathrm{F}}\left(A_{\mathrm{F}}=1 / \cos \theta+1 / \cos \xi\right.$, where $\theta$ is the solar zenith angle and $\xi$ is the viewing angle of the satellite), water column density, and dry-air column density - are also published with the IMAP-DOAS v6.0 $\mathrm{XCH}_{4}$ product.

The estimated single-retrieval precision is scenedependent and averages roughly $1.5 \%$, or $25 \mathrm{ppb}$ (Frankenberg et al., 2011). With this order of instrument precision, SCIAMACHY cannot resolve day-to-day variability of emissions but can strongly constrain a multi-year average (Turner et al., 2015). The retrieving algorithm firstly calculates $\mathrm{CH}_{4}$ total column density $\Omega_{\mathrm{CH}_{4}}\left(\right.$ molecules $\left.\mathrm{cm}^{-2}\right)$ :

$\Omega_{\mathrm{CH}_{4}}=\Omega_{\mathrm{A}}+\boldsymbol{a}^{\mathrm{T}}\left(\boldsymbol{\omega}-\boldsymbol{\omega}_{\mathrm{A}}\right)$,

where $\omega$ is the true 10-layer sub-column densities of $\mathrm{CH}_{4}$ (molecules $\mathrm{cm}^{-2}$ ), $\omega_{\mathrm{A}}$ is the 10-layer prior $\mathrm{CH}_{4}$ sub-column density (molecules $\mathrm{cm}^{-2}$ ), $\Omega_{\mathrm{A}}$ is the corresponding a priori $\mathrm{CH}_{4}$ total column density, and $\boldsymbol{a}$ is an averaging kernel vector that defines the sensitivity of the retrieved total column to each sub-column in $\omega$. To account for the impact of aerosol scattering and instrument effects on the observed light path, Frankenberg et al. (2006) used the $\mathrm{CO}_{2}$ column density $\Omega_{\mathrm{CO}_{2}}$ as a proxy to normalize and convert $\Omega_{\mathrm{CH}_{4}}$ to a column mixing ratio $\mathrm{XCH}_{4}(\mathrm{ppb})$ :

$\mathrm{XCH}_{4}=\left(\Omega_{\mathrm{CH}_{4}} / \Omega_{\mathrm{CO}_{2}}\right) \mathrm{XCO}_{2}$,

where $\mathrm{XCO}_{2}$ is the column-weighted mixing ratio of $\mathrm{CO}_{2}$ from NOAA's CarbonTracker $\mathrm{CO}_{2}$ measurement and modeling system. $\mathrm{CO}_{2}$ is used as a proxy because it is retrieved in a spectrally neighboring fitting window and, relative to $\mathrm{CH}_{4}$, its mixing ratio is known with much higher precision.

The quality of SCIAMACHY observations is controlled by a filtering scheme that selects only daytime, over-land scenes that are cloud-free or partially cloudy, and good fitting accuracy (http://www.temis.nl/climate/docs/TEMIS_SCIA_ CH4_IMAPv60_PSD_v2_6.pdf). Further, a surface elevation filter is applied to filter out observations that are different from the model grids at surface altitude by more than $250 \mathrm{~m}$ (Bergamaschi et al., 2009; Alexe et al., 2015). This filtering process ensures that the atmospheric columns seen by SCIAMACHY are well represented by the model columns. To avoid spurious outliers that may have a large impact on the inversion, $\mathrm{XCH}_{4}$ retrievals of less than $1500 \mathrm{ppb}$ or larger than $2500 \mathrm{ppb}$ are discarded (Alexe et al., 2015). For the pan-Arctic, most of the qualified $\mathrm{XCH}_{4}$ retrievals were recorded in the summertime, when local solar zenith angles are higher, surface reflectance is lower, and impact of Arctic vortex is smaller. Figure 1 shows the SCIAMACHY retrievals $\left(n=37743\right.$ ) of the weighted column-average $\mathrm{CH}_{4}$ dry mixing ratio for July-September 2005 in the pan-Arctic that have passed all quality control tests.

\subsection{Surface observations}

The NOAA/ESRL Carbon Cycle Cooperative Global Air Sampling Network provides high-precision weekly flask measurements of surface atmospheric $\mathrm{CH}_{4}$ dry-air mole fraction (Dlugokencky et al., 2014) that were calibrated against the WMO X2004 $\mathrm{CH}_{4}$ standard scale maintained at NOAA (Dlugokencky et al., 2005). Due to the coarse resolution of the GEOS-Chem model, we include only marine and continental background sites and exclude sites that are strongly influenced by sub-grid local sources (Alexe et al., 2015), as listed in Table S1 in the Supplement. The flask-air samples in the NOAA/ESRL network that were taken from regular ship cruises in the Pacific Ocean serve to evaluate simulated surface mixing ratios of global inversions over the remote ocean and downwind the continental sources (Alexe et al., 2015). Figure 1 shows the Arctic sites that were used for data assimilation and nested-grid inversion evaluation.

\subsection{Aircraft campaign observations}

To derive the bias of SCIAMACHY $\mathrm{CH}_{4}$ retrievals overpassing the pan-Arctic and evaluate the modeled $\mathrm{CH}_{4}$ vertical profiles in the troposphere, we used $\mathrm{CH}_{4}$ measurements that were collected by three aircraft campaigns: the NOAA/ESRL Carbon Cycle Cooperative Global Air Sampling Network's aircraft program (http://www.esrl.noaa.gov/ gmd/ccgg/aircraft/data.html; Sweeney et al., 2015), the National Institute for Environmental Studies (NIES) aircraft program (Machida et al., 2001; Sasakawa et al., 2013), and NASA's Arctic Research of the Composition of the Troposphere from Aircraft and Satellite (ARCTAS) mission (Jacob et al., 2010). For the NOAA/ESRL aircraft mission, $\mathrm{CH}_{4}$ was routinely collected using $0.7 \mathrm{~L}$ silicate glass flasks on planned flights with maximum altitude limits of 300 $350 \mathrm{hPa}$. The sampling vertical resolution is up to $400 \mathrm{~m}$ in the boundary layer, and all samples were analyzed by NOAA/ESRL in Boulder, Colorado. For the NIES aircraft mission, air samples were collected in $550 \mathrm{~mL}$ glass flasks over Surgut, western Siberia $\left(61.5^{\circ} \mathrm{N}, 73.0^{\circ} \mathrm{E}\right)$, at altitude ranging from 0.5 to $7 \mathrm{~km}$ with $0.5-1.5 \mathrm{~km}$ intervals. The precision of gas chromatograph analysis for $\mathrm{CH}_{4}$ measurement was estimated to be $1.7 \mathrm{ppb}$, and the NIES-94 scale used in analysis was higher than the NOAA/GMD scale by $3.5-4.6 \mathrm{ppb}$ in a range of $1750-1840 \mathrm{ppb}$. In ARCTAS, $\mathrm{CH}_{4}$ was measured over northern Canada by the Differential Absorption CO Measurement (DACOM) tunable diode laser instrument with an estimated accuracy/precision of $1 \% / 0.1 \%$. Central locations of their flights in the pan-Arctic are shown in Fig. 1. Table S2 lists the locations and profiles of the NOAA/ESRL aircraft mission flights used in evaluation. 


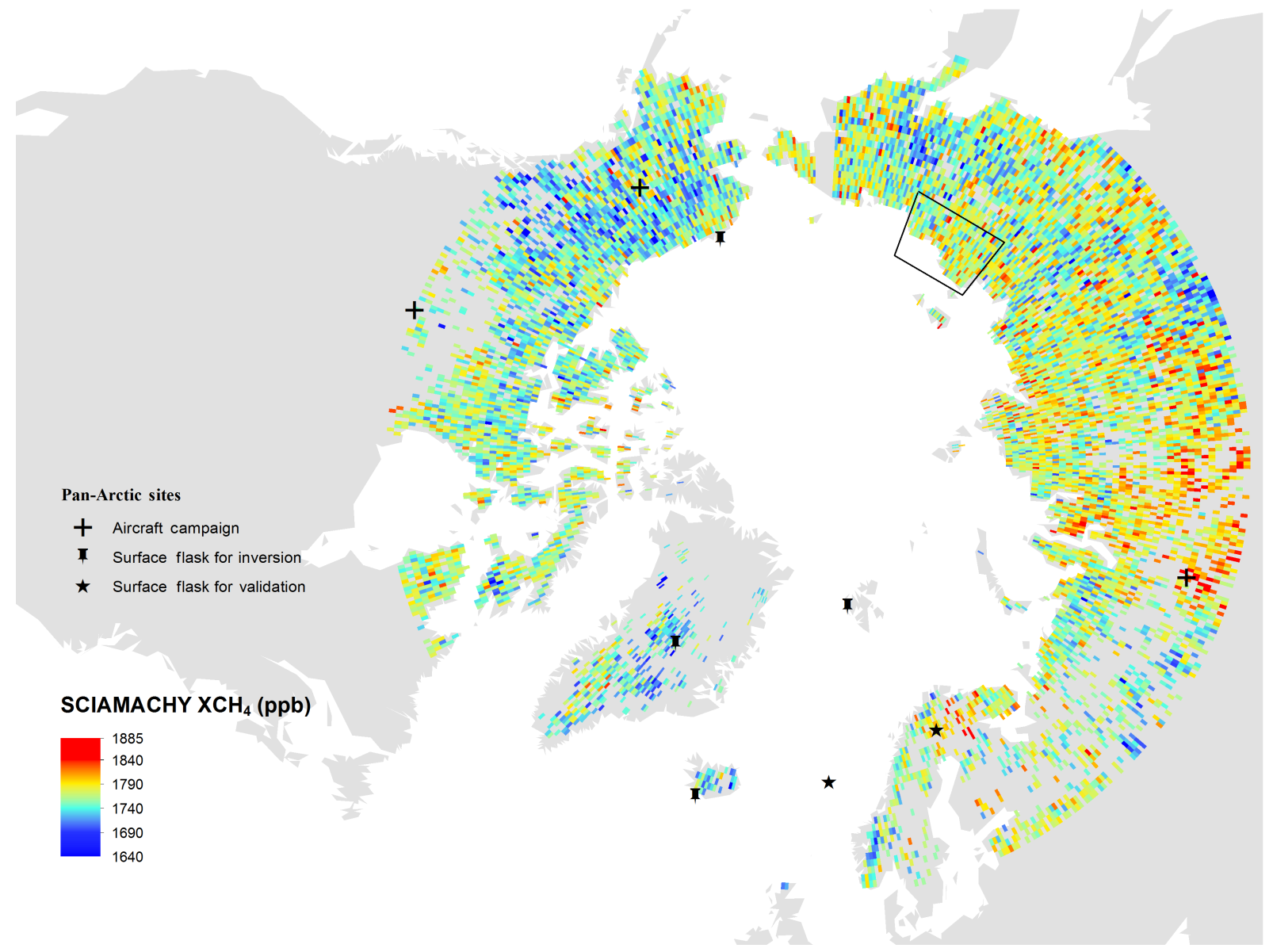

Figure 1. SCIAMACHY retrievals $(n=37743)$ of the weighted column-average $\mathrm{CH}_{4}$ dry-mole fractions for July-September 2005 in the pan-Arctic that have passed all quality control tests described in Sect. 2.1, and the locations of surface flask stations and aircraft missions used for data assimilation or inversion evaluation.

\section{Modeling}

Here we describe the prior emissions, the forward model, and the inversion method used to optimize $\mathrm{CH}_{4}$ emissions in the pan-Arctic on the basis of SCIAMACHY and NOAA/ESRL observations.

\subsection{Wetland and lake $\mathrm{CH}_{4}$ emissions}

$\mathrm{CH}_{4}$ emissions estimated by the inverse modeling method can be sensitive to the choice of prior wetland $\mathrm{CH}_{4}$ fluxes (Bergamaschi, 2007). To assess this sensitivity, we used wetland $\mathrm{CH}_{4}$ emissions simulated by six well-known wetland biogeochemical models (CLM4Me: the Community Land Model 4 (CLM4) $\mathrm{CH}_{4}$ biogeochemistry model; DLEM: the Dynamic Land Ecosystem Model; BERN: the LundPotsdam-Jena dynamic global vegetation model - the University of Bern version; WSL: the Lund-Potsdam-Jena dynamic global vegetation model - the Swiss Federal Research Institute version; ORCHIDEE: the Organising Carbon and Hydrology in Dynamic Ecosystems model; SDGVM: the Sheffield Dynamic Global Vegetation Model) to set up six different inverse modeling experiments. All wetland $\mathrm{CH}_{4}$ simulations follow the same protocol of the WETland and Wetland $\mathrm{CH}_{4}$ Inter-comparison of Models Project (WETCHIMP) as described in Melton et al. (2013) and Wania et al. (2013). Melton et al. (2013) demonstrated that the difference of these estimates primarily arises from the model distinction in $\mathrm{CH}_{4}$ biogeochemistry and wetland hydrology. These models estimated that the annual global $\mathrm{CH}_{4}$ emissions from wetlands during 2004-2005 were in the range of 121.7-278.1 $\mathrm{Tg} \mathrm{yr}^{-1}$ (Fig. S1 in Supplement), and wetland $\mathrm{CH}_{4}$ emissions are the highest in tropical regions (e.g., the Amazon, Southeast Asia, and tropical Africa) where extensive floodplains and warm environment coexist. In the panArctic, the modeled annual wetland $\mathrm{CH}_{4}$ emissions in 2005 were in the range of 9.1-20.9 $\mathrm{Tg} \mathrm{yr}^{-1}$ (Fig. 2), and their spatial distribution was mainly controlled by the modeled or mapped wetland coverage (Melton et al., 2013). As shown in Fig. 2, because of some consistency in simulating wetland hydrology, nearly all models suggest that there are high $\mathrm{CH}_{4}$ 

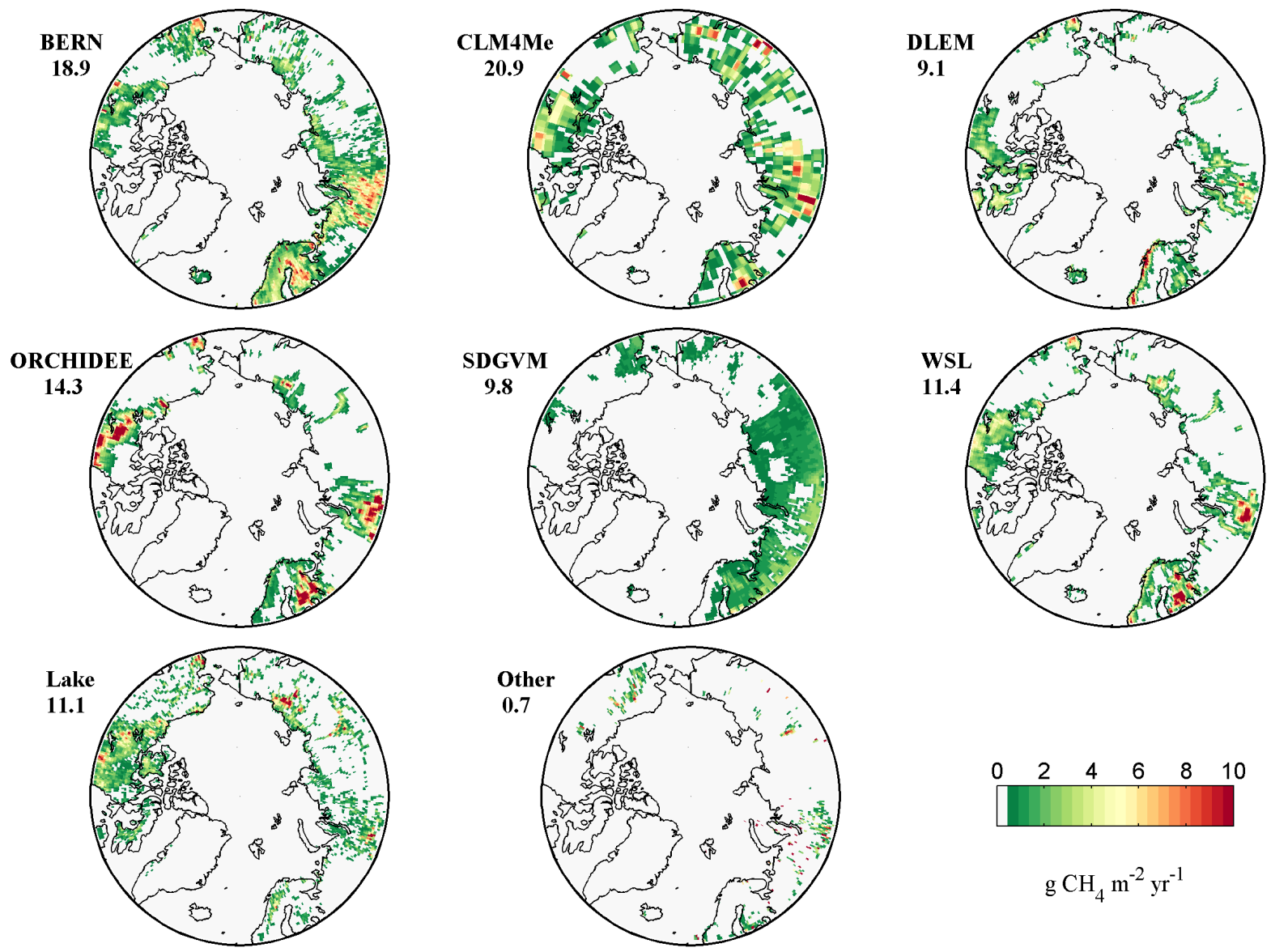

Figure 2. Prior average $\mathrm{CH}_{4}$ fluxes from wetlands, lakes, and other sources (i.e., anthropogenic and biomass burning) in 2005 used for the pan-Arctic nested-grid inversions at $1 / 2^{\circ} \times 2 / 3^{\circ}$ resolution. Annual total emission for each pan-Arctic source is presented in units of $\mathrm{Tg} \mathrm{CH}_{4} \mathrm{yr}^{-1}$.

fluxes in the west Siberian lowlands, Finland, and the Canadian Shield.

Lakes, permanent still-water bodies without direct connection to the sea, are abundant in the pan-Arctic (Lehner and Döll, 2004). Recent studies indicated that pan-Arctic lakes could contribute a significant amount of $\mathrm{CH}_{4}$ to the atmosphere (Walter et al., 2006; Tan and Zhuang, 2015a) and that the emissions could be driven by factors different from wetland emissions, e.g., the supply of labile yedoma permafrost carbon (Walter et al., 2006) and deep water mixing (Schubert et al., 2012). Because the WETCHIMP models cannot account for this source, we used a one-dimension processbased lake biogeochemical model, bLake4Me, to simulate $\mathrm{CH}_{4}$ emissions from pan-Arctic lakes (Tan et al., 2015; Tan and Zhuang, 2015a). The bLake4Me model explicitly parameterizes the control of temperature and carbon substrate availability on methanogenesis, the control of temperature and oxygen level on methanotrophy, and the transport of gaseous $\mathrm{CH}_{4}$ by diffusion and ebullition. A detailed model description and evaluation can be found in Tan et al. (2015). Model quantification of $\mathrm{CH}_{4}$ emissions from all lakes north of $60^{\circ} \mathrm{N}$ was described by Tan and Zhuang (2015a, b). On average, the estimated $\mathrm{CH}_{4}$ emissions from pan-Arctic lakes during the studied period are approximately $11 \mathrm{Tg} \mathrm{CH}_{4} \mathrm{yr}^{-1}$; see Fig. 2.

\subsection{GEOS-Chem model}

Atmospheric $\mathrm{CH}_{4}$ mole fractions are simulated by GEOSChem v9-01-03 (http://acmg.seas.harvard.edu/geos/index. html), a global 3-D CTM model (Bey et al., 2001). For the period of 2004-2005, GEOS-Chem is driven by GEOS-5 meteorological (hereafter GEOS-5 met) data from NASA's Global Modeling Assimilation Office (GMAO). The GEOS5 met data have horizontal resolution of $1 / 2^{\circ}$ latitude $\times 2 / 3^{\circ}$ longitude, temporal resolution of $6 \mathrm{~h}$, and 72 hybrid sigmapressure levels extending from Earth's surface to $0.01 \mathrm{hPa}$. In contrast to the global GEOS-Chem model, the nested-grid version does not include algorithms for handling advection near the North and South Pole (Lin and Rood, 1996). To avoid polar grid boxes, we crop the native $1 / 2^{\circ} \times 2 / 3^{\circ}$ resolution GEOS-5 met data to a window region $\left(180^{\circ} \mathrm{W}-180^{\circ} \mathrm{E}\right.$ 
and $80-56^{\circ} \mathrm{N}$ ) for the pan-Arctic nested grid. To make it consistent with the bLake4Me model, only $\mathrm{CH}_{4}$ emissions north of $60^{\circ} \mathrm{N}$ are analyzed. We expect that the avoidance of the North Pole only has a minor impact on our inversions because according to Miyazaki et al. (2008) the Northern Hemisphere (NH) extratropics during summer have a slow meanmeridional circulation and inactive wave activity but strong vertical transport. Boundary conditions for nested-grid simulations are produced using the same period GEOS-Chem $4^{\circ} \times 5^{\circ}$ resolution global-scale forward runs at $3 \mathrm{~h}$ intervals.

The GEOS-Chem $\mathrm{CH}_{4}$ simulation was originally introduced by Wang et al. (2004) and updated by Pickett-Heaps et al. (2011). As described by Wecht et al. (2014), the prior anthropogenic sources - including oil/gas production, coal mining, livestock, waste treatment, rice paddies, biofuel burning, and other processes - were extracted from the Emission Database for Global Atmospheric Research v4.2 (EDGAR4.2) with $0.1^{\circ} \times 0.1^{\circ}$ resolution and no seasonality (European Commission, Joint Research Centre/Netherlands Environmental Assessment Agency, 2009). $\mathrm{CH}_{4}$ emissions from termites and biomass burning were obtained from the study of Fung et al. (1991) and the daily Global Fire Emissions Database Version 3 (GFED3) of van der Werf et al. (2010), respectively. $\mathrm{CH}_{4}$ emissions from wetlands and lakes were simulated by biogeochemical models described in Sect. 3.1. Atmospheric $\mathrm{CH}_{4}$ is mainly removed by tropospheric oxidation initiated by reaction with tropospheric $\mathrm{OH}$, which was computed using a 3-D OH climatology of monthly average concentrations from a previous simulation of tropospheric chemistry (Park et al., 2004). The global mean pressure-weighted tropospheric $\mathrm{OH}$ concentration is $10.8 \times 10^{5}$ molecules $\mathrm{cm}^{-3}$. For minor sinks, $\mathrm{CH}_{4}$ uptake by upland soils was derived from Fung et al. (1991), and $\mathrm{CH}_{4}$ oxidation in the stratosphere was calculated from the archived $\mathrm{CH}_{4}$ loss frequency described by Murray et al. (2012). The resulting atmospheric lifetime of $\mathrm{CH}_{4}$ is about 8.9 years, consistent with the observational constraint of $9.1 \pm 0.9$ years (Prather et al., 2012). We regridded and cropped the anthropogenic and natural $\mathrm{CH}_{4}$ emissions in EDGAR4.2, GFED3, and Fung et al. (1991) for our nested pan-Arctic domain using the Harvard-NASA Emissions Component (HEMCO) software (Keller et al., 2014), marked as "other" in Fig. 2. Compared to $\mathrm{CH}_{4}$ emissions from natural sources, these emissions were relatively small in $2005\left(\sim 2.1 \mathrm{Tg} \mathrm{yr}^{-1}\right)$.

\subsection{Inversion method}

Atmospheric inversion is a procedure for using observations of atmospheric gases as constraints to estimate surface gas fluxes. The inverse problem can be characterized by the solution of

$\boldsymbol{y}=F(\boldsymbol{x})+\boldsymbol{\varepsilon}$.
By applying Bayesian theorem and assuming Gaussian errors, the inverse problem can be solved by minimizing the cost function, $J(x)$, that measures the model deviations from both prior assumptions and observations (Enting et al., 2002; Kopacz et al., 2009):

$$
\begin{aligned}
J(\boldsymbol{x}) & =(F(\boldsymbol{x})-\boldsymbol{y})^{\mathrm{T}} \mathbf{C}_{\mathrm{d}}^{-1}(F(\boldsymbol{x})-\boldsymbol{y}) \\
& +\gamma\left(\boldsymbol{x}-\boldsymbol{x}_{0}\right)^{\mathrm{T}} \mathbf{C}_{x_{0}}^{-1}\left(\boldsymbol{x}-\boldsymbol{x}_{0}\right),
\end{aligned}
$$

where $\boldsymbol{y}$ is a vector of observations from SCIAMACHY and NOAA/ESRL, $F$ is a model operator that maps emissions to observations, $\boldsymbol{x}$ represents $\mathrm{CH}_{4}$ emissions to be constrained, $\boldsymbol{x}_{0}$ is the a priori estimate of $\boldsymbol{x}, \mathbf{C}_{\mathrm{d}}$ is the observational error covariance matrix that includes contributions from model error, representation error (sampling mismatch between observations and the model) and measurement error, and $\mathbf{C}_{x_{0}}$ is the parameter error covariance matrix (containing the uncertainties of the parameters and their correlations). The regularization parameter $\gamma$ controls the relative constraints applied by the observational and a priori parts of $J(x)$ (Kopacz et al., 2009). In the adjoint method, $\gamma$ is not fixed at unity but determined by analyzing its influence on the minimum of $J(x)$ (Henze et al., 2007; Kopacz et al., 2009).

Minimization of $J(x)$ yields the following expression for the maximum a posteriori solution for the state vector $\hat{\boldsymbol{x}}$ and its associated error covariance $\hat{\mathbf{C}}_{x}$ (Rodgers, 2000):

$$
\begin{gathered}
\hat{\boldsymbol{x}}=\boldsymbol{x}_{0}+\left(\left(\nabla_{x} F\right)^{\mathrm{T}} \mathbf{C}_{\mathrm{d}}^{-1} \nabla_{x} F+\gamma \mathbf{C}_{x_{0}}^{-1}\right)^{-1} \\
\left(\nabla_{x} F\right)^{\mathrm{T}} \mathbf{C}_{\mathrm{d}}^{-1}\left(\boldsymbol{y}-F\left(\boldsymbol{x}_{0}\right)\right), \\
\hat{\mathbf{C}}_{x}^{-1}=\left(\nabla_{x} F\right)^{\mathrm{T}} \mathbf{C}_{\mathrm{d}}^{-1} \nabla_{x} F+\gamma \mathbf{C}_{x_{0}}^{-1},
\end{gathered}
$$

where $\nabla_{x} F$ is the Jacobian matrix of the forward model. $J(x)$ is minimized iteratively through successive forward and backward simulations with the GEOS-Chem model and its adjoint, developed by Henze et al. (2007) and previously applied to $\mathrm{CO}, \mathrm{CO}_{2}$, and $\mathrm{CH}_{4}$ source inversions (Jiang et al., 2011; Deng et al., 2014; Wecht et al., 2014). The GEOS-Chem adjoint model is a 4-dimensional variational data assimilation (4DVAR) inverse modeling system that allows optimization of a very large number of parameters using at the same time very large sets of observational data, such as satellite data. Rather than optimizing $\mathrm{CH}_{4}$ emissions directly, it optimizes an exponential scale factor $e_{x}$ $\left(e_{x}=\ln \left(\boldsymbol{x} / x_{0}\right)\right)$ at each grid cell to avoid negative emissions. The posterior error covariance $\hat{\mathbf{C}}_{x}$ could be approximated by the Davidon-Fletcher-Powell (DFP) or the limitedmemory Broyden-Fletcher-Goldfarb-Shanno (L-BFGS) optimization algorithm (Singh et al., 2011; Deng et al., 2014). But the performances of these deterministic methods are usually not promising, subjecting to the choice of the initial Hessian, so-called preconditioning (Bousserez et al., 2015). In contrast, approximating $\hat{\mathbf{C}}_{x}$ by stochastic methods, i.e., Monte Carlo sampling and gradient-based randomization, could help avoid the impact of setting the initial Hessian 

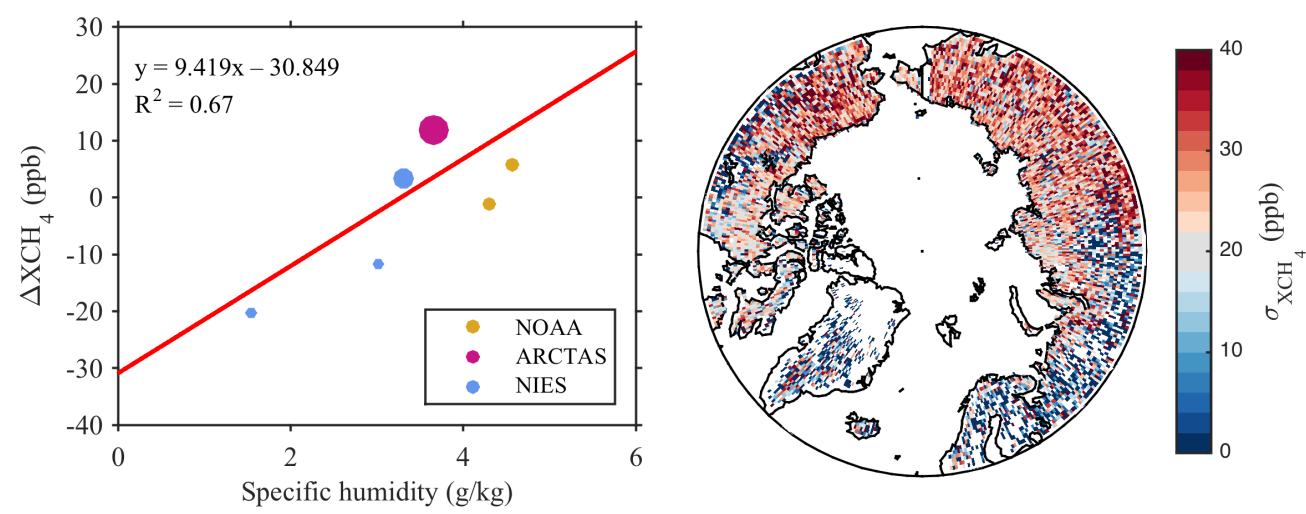

Figure 3. Bias correction function (left) and standard deviation (right) for SCIAMACHY retrievals overpassing the pan-Arctic. $\triangle \mathrm{XCH}_{4}$ is the difference between SCIAMACHY and column-average mixing ratios mapped from aircraft vertical profiles. The red line on the left shows a linear regression weighted by the number (represented by circle size) of SCIAMACHY retrievals.

(Bousserez et al., 2015). For example, Bousserez et al. (2015) demonstrated that for high-dimensional inverse problems using a Monte Carlo stochastic approach that samples ensemble members by perturbing $\boldsymbol{x}_{0}$ and $\boldsymbol{y}$ in line with $\mathbf{C}_{x_{0}}$ and $\mathbf{C}_{\mathrm{d}}$, respectively, could guarantee a low relative error $(10 \%)$ in the variance with as few as 50 members. In this study, the posterior uncertainty of nested-grid inversions was estimated using this method.

For prior emissions, their uncertainties were set as $100 \%$ in each grid box, and spatial correlation was set as an efolding function with spatial correlation lengths of $500 \mathrm{~km}$ at the global $4^{\circ} \times 5^{\circ}$ resolution and of $300 \mathrm{~km}$ at the nestedgrid $1 / 2^{\circ} \times 2 / 3^{\circ}$ resolution (Bergamaschi et al., 2009). Six global coarse-resolution inversions using different wetland emission scenarios and assimilating both surface $\mathrm{CH}_{4}$ measurements and satellite $\mathrm{CH}_{4}$ retrievals were performed during the period of January-December 2005. These inversions provided boundary conditions for the following nestedgrid inversions. For $1 / 2^{\circ} \times 2 / 3^{\circ}$ nested-grid inversions, we ran the adjoint model 50 times over the period of JulySeptember 2005 for each of 12 scenarios: six wetland scenarios by two data assimilation scenarios. The two data assimilation scenarios include one scenario assimilating only NOAA/ESRL measurements and another scenario assimilating both NOAA/ESRL measurements and SCIAMACHY retrievals. As described above, the 50-member ensemble run is for the calculation of posterior estimate uncertainty. The steps to construct optimal initial conditions for global and nested inversions are described in the Supplement. As in Wecht et al. (2014), observations in the first week were not assimilated, and each optimization was run iteratively at least 40 times until the reduction of its cost function became less than $0.5 \%$ with each successive iteration. In the GEOSChem adjoint model, optimization changes its course automatically if local minimum is reached.

\subsection{Satellite retrieval bias correction}

The importance of bias correction for the assimilation of satellite retrievals has been discussed in many earlier studies (Bergamaschi et al., 2007, 2009, 2013; Fraser et al., 2013; Cressot et al., 2014; Houweling et al., 2014; Wecht et al., 2014; Alexe et al., 2015; Turner et al., 2015). Usually, these studies represented satellite retrieval bias as a regression function of one proxy parameter, e.g., latitude, air mass factor, or specific humidity. The air mass factor was used as a proxy parameter by some studies due to its correlation with spectroscopic errors and residual aerosol errors (Cressot et al., 2014; Houweling et al., 2014), and specific humidity was used because water vapor is the main cause of SCIAMACHY seasonal bias that lags the variations of solar zenith angle (Houweling et al., 2014). Relative to the air mass factor and humidity, latitude can represent the changes in both solar zenith angle and climate variables (Bergamaschi et al., 2007, 2009, 2013) and thus was used by more studies. Considering that different proxies can account for different errors, the system bias of satellites may be better represented by multiple proxy parameters.

To test this hypothesis, we compared the performance of three traditional one-proxy methods (latitude $\varphi$, air mass factor $A_{\mathrm{F}}$, specific humidity $H_{\mathrm{S}}$ ) and two new two-proxy methods (latitude + humidity, air mass factor + humidity), listed in Table 1. These methods were evaluated using two reference values: the difference between the satellite-retrieved and the GEOS-Chem-modeled $\mathrm{CH}_{4}$ column mixing ratios and the Bayesian information criterion (BIC) score. The BIC criterion is widely used for regression model selection and aims to award a model that fits measurements with the least model parameters. In the study, we would select the bias correction method that gives the smallest difference and the lowest BIC score. In our experiments, all bias correction functions were updated monthly. As listed in Table 1, the "latitude- 
Table 1. Summary of bias correction methods and of mean absolute satellite-model difference (ppb) for 2003-2005 before and after applying bias correction. $\triangle \mathrm{BIC}$ is the BIC score increase of a bias correction method when referring to the latitude-only method.

\begin{tabular}{llrrr}
\hline & $\begin{array}{l}\text { Bias correction } \\
\text { function* }\end{array}$ & $\begin{array}{r}\text { Mean absolute } \\
\text { difference }\end{array}$ & $\Delta \mathrm{BIC}$ & $R^{2}$ \\
\hline No correction & & 9.271 & & \\
Latitude only & $p_{0}+p_{1} \varphi+p_{2} \varphi^{2}$ & 6.305 & & 0.62 \\
Air mass factor only & $p_{0}+p_{1} A_{\mathrm{F}}$ & 7.071 & 161 & 0.52 \\
Humidity only & $p_{0}+p_{1} H_{\mathrm{S}}$ & 6.786 & 73 & 0.56 \\
Latitude + humidity & $p_{0}+p_{11} \varphi+p_{12} \varphi^{2}+p_{21} H_{\mathrm{S}}$ & 6.230 & -7 & 0.62 \\
Air mass factor + humidity & $p_{0}+p_{11} A_{\mathrm{F}}+p_{21} H_{\mathrm{S}}$ & 6.396 & 12 & 0.60 \\
\hline
\end{tabular}

$* p_{0}, p_{1}, p_{2}, p_{11}, p_{12}$, and $p_{21}$ are regression parameters.

only" correction performs the best among the three singleproxy correction methods and is only slightly worse than the "latitude + humidity" correction method. The "air-massfactor-only" method does not work as well in our experiment. Turner et al. (2015) suggested that it could be attributed to a potential bias in the GEOS-Chem simulation of $\mathrm{CH}_{4}$ in the polar stratosphere. As the latitude + humidity method has the smallest model-data difference and the lowest BIC score, we applied it for satellite bias correction in all global inversions.

For SCIAMACHY retrievals overpassing the pan-Arctic, because the modeled atmospheric $\mathrm{CH}_{4}$ could be less reliable, we used another bias correction method. According to a comparison between SCIAMACHY and the highprecision Total Carbon Column Observing Network (TC$\mathrm{CON}$ ) measurements, the system bias of SCIAMACHY retrievals could be closely correlated with specific humidity averaged over the lowest $3 \mathrm{~km}$ of the atmosphere (Houweling et al., 2014). And Wecht et al. (2014) has demonstrated that this humidity-proxy method shows promising performance in debiasing SCIAMACHY retrievals overpassing North America. In this study, we sought a similar linear regression relationship between SCIAMACHY bias and specific humidity. First, we detected the SCIAMACHY bias by comparing SCIAMACHY retrievals with $\mathrm{CH}_{4}$ vertical profiles measured by the NOAA/ESRL aircraft mission over Alaska, USA; the NIES aircraft mission over Siberia, Russia; and the NASA/ARCTAS aircraft mission over Alberta, Canada. Before comparison, these $\mathrm{CH}_{4}$ vertical profiles had been mapped to the SCIAMACHY retrieval pressure grid using Eqs. (1) and (2). Figure 3 (left) shows that the retrieved system bias $\left(\triangle \mathrm{XCH}_{4}\right)$ has a negative relationship with air humidity. Because the pan-Arctic is normally dry, SCIAMACHY retrievals could be lower than atmospheric $\mathrm{CH}_{4}$ column-average mixing ratios on most days.

After bias correction, the error variances of SCIAMACHY retrievals were estimated using the relative residual error (RRE) method described by Heald et al. (2004). Figure S2 shows the error variances of SCIAMACHY retrievals on a global scale, and Fig. 3 (right) shows the error variances in the nested grid. In both global and nested-grid inversions, the total error of individual SCIAMACHY retrievals is assumed to be at least $1.5 \%$ (Bergamaschi et al., 2007; Frankenberg et al., 2011). The observational error of the NOAA/ESRL $\mathrm{CH}_{4}$ mixing ratios is estimated as the sum of measurement error $(\sim 0.2 \%)$ and representation error. Similar to satellite retrievals, the representation error of surface measurements is defined as the standard deviation of surface $\mathrm{CH}_{4}$ concentration differences between NOAA/ESRL measurements and GEOS-Chem.

\section{Results and discussion}

\subsection{Optimized global $\mathrm{CH}_{4}$ emissions}

As listed in Table 2, when both NOAA/ESRL measurements and SCIAMACHY retrievals are assimilated, the posterior estimates of total emissions in 2005 show good convergence at a narrow range of 496.4-511.5 $\mathrm{Tg} \mathrm{CH}_{4} \mathrm{yr}^{-1}$, although our six prior scenarios span in a wide range (471.5$627.8 \mathrm{Tg} \mathrm{CH}_{4} \mathrm{yr}^{-1}$ ). Because the total of global emissions is constrained by the atmospheric $\mathrm{CH}_{4}$ burden and lifetime, this convergence probably suggests that surface measurements from the NOAA/ESRL network are of sufficient density and accuracy to represent the global $\mathrm{CH}_{4}$ burden if the $\mathrm{CH}_{4}$ lifetime is correct. In contrast, the posterior $\mathrm{CH}_{4}$ emissions differ largely between different wetland emission scenarios in the TransCom3 (Atmospheric Tracer Transport Model Intercomparison Project) land regions. For example, in the DLEM inversion, the estimated $\mathrm{CH}_{4}$ emissions from the Eurasian temperate region are as large as $146.1 \mathrm{Tg} \mathrm{CH}_{4} \mathrm{yr}^{-1}$. But in the CLM4Me inversion, the total of these emissions is only $84.9 \mathrm{Tg} \mathrm{CH}_{4} \mathrm{yr}^{-1}$. Also, for $\mathrm{CH}_{4}$ emissions from the South American tropical region, the estimate is $31.4 \mathrm{Tg} \mathrm{CH}_{4} \mathrm{yr}^{-1}$ in the DLEM inversion but nearly 2 times larger (62.3 $\mathrm{Tg} \mathrm{CH}_{4} \mathrm{yr}^{-1}$ ) in the SDGVM inversion. There are several possible explanations for the large differences between the scenarios: high-precision surface measurements could be not of sufficient density in regional scales, satellite retrievals could be not of sufficient accuracy, and the GEOSChem model and its priors could be not of high enough tem- 

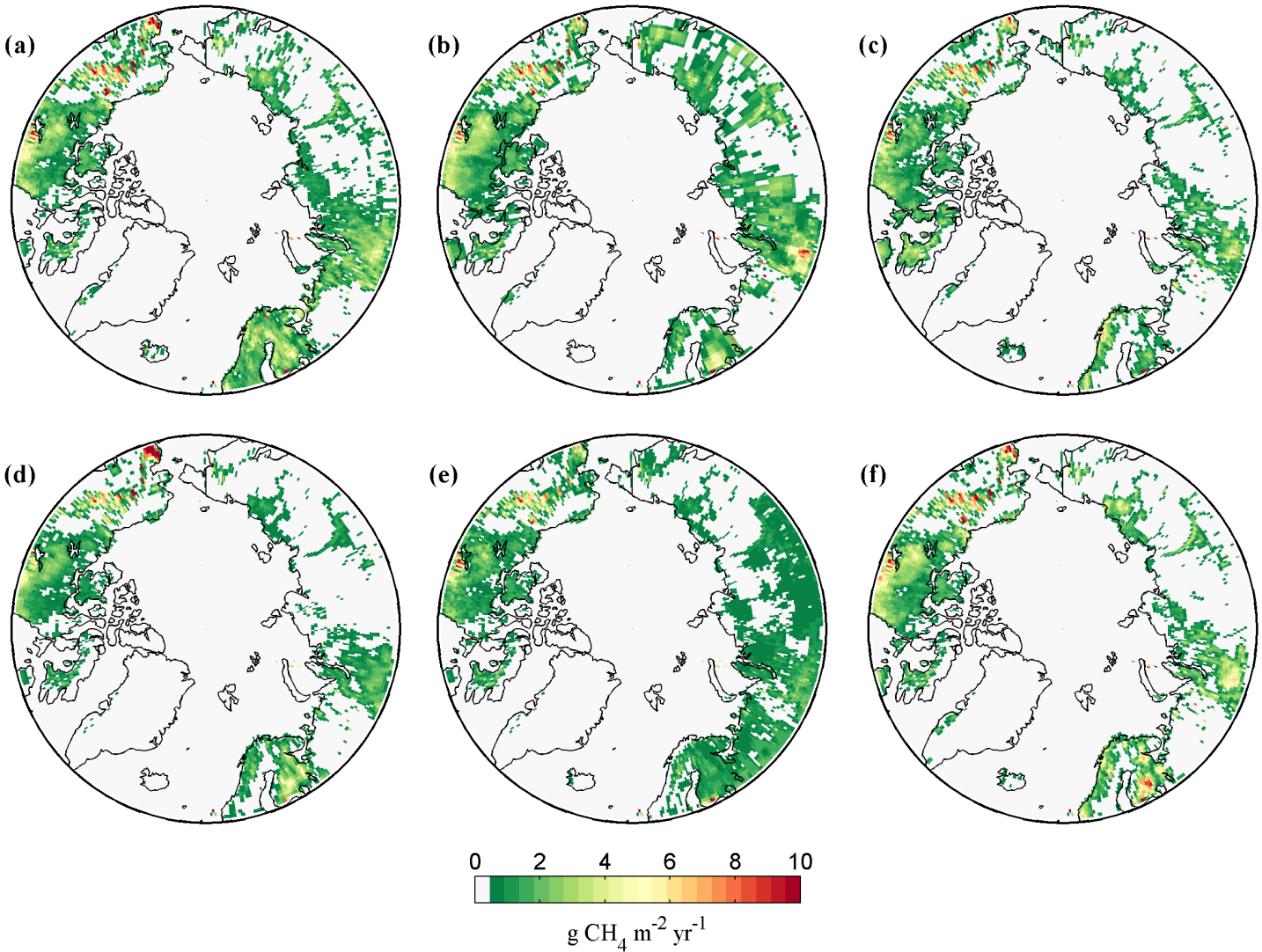

Figure 4. Optimized pan-Arctic $\mathrm{CH}_{4}$ fluxes in 2005 at $1 / 2^{\circ} \times 2 / 3^{\circ}$ resolution using both SCIAMACHY and NOAA/ESRL observations. (a) BERN; (b) CLM4Me; (c) DLEM; (d) ORCHIDEE; (e) SDGVM; (f) WSL.

poral and spatial resolutions to resolve satellite retrievals. A detailed comparison between our estimates and previous inversion studies at the global scale is presented in the Supplement.

\subsection{Optimized pan-Arctic $\mathrm{CH}_{4}$ emissions}

\subsubsection{Regional $\mathrm{CH}_{4}$ emissions}

When using both surface measurements and satellite retrievals, our estimated $\mathrm{CH}_{4}$ emissions over the pan-Arctic are in the range of 11.9-28.5 $\mathrm{Tg} \mathrm{CH}_{4} \mathrm{yr}^{-1}$. The simulation is the largest in the ORCHIDEE scenario and the smallest in the SDGVM scenario: $24.9 \pm 3.6$ and $16.1 \pm 4.2 \mathrm{Tg} \mathrm{CH}_{4} \mathrm{yr}^{-1}$, respectively. Regionally, posterior $\mathrm{CH}_{4}$ emissions from Alaska, northern Canada, northern Europe, and Siberia are 0.3-3.4, 1.3-7.9, 0.8-8.1 and 4.4-14.9 $\mathrm{Tg} \mathrm{CH}_{4} \mathrm{yr}^{-1}$, respectively. Same as the global inversions, the difference of the nested-grid inversions between different scenarios is much larger than the total uncertainty of priors and observations of each scenario: $16.6 \mathrm{Tg} \mathrm{CH}_{4} \mathrm{yr}^{-1}$ vs. $5.5 \mathrm{Tg} \mathrm{CH}_{4} \mathrm{yr}^{-1}$. In these regions, $\mathrm{CH}_{4}$ emissions from Siberia are more uncertain (Fig. 5), a possible indication of the lack of highquality measurements in Siberia for assimilation. Our results also indicate that the assimilation of SCIAMACHY retrievals overpassing the pan-Arctic can reduce the estimate uncertainty. For example, for the BERN scenario, the posterior uncertainty is about $18 \%$, much smaller than the inversion that only assimilates NOAA/ESRL measurements $(27 \%)$. And for the CLM4Me scenario, the posterior uncertainty increases from 16 to $23 \%$ when only surface measurements are assimilated. Our estimates are consistent with other inverse modeling estimates. For example, Kirschke et al. (2013) reviewed a series of top-down estimation of $\mathrm{CH}_{4}$ emissions and suggested that $\mathrm{CH}_{4}$ emissions north of $60^{\circ} \mathrm{N}$ could be in the range of $12-28 \mathrm{TgCH}_{4} \mathrm{yr}^{-1}$, very close to our estimate. This consistency could reflect the robustness of our nested-grid GEOS-Chem adjoint model and the good constraint of the NOAA/ESRL sites over the pan-Arctic on the atmospheric $\mathrm{CH}_{4}$ field. Our estimates also imply that $\mathrm{CH}_{4}$ emission from the pan-Arctic could constitute a large fraction of $\mathrm{CH}_{4}$ emissions in the northern high latitudes $\left(>50^{\circ} \mathrm{N}\right)$. Based on the estimate (50 $\mathrm{Tg} \mathrm{CH}_{4} \mathrm{yr}^{-1}$ ) of Monteil et al. (2013), we calculated that $29.2-60.8 \%$ of $\mathrm{CH}_{4}$ emissions in the northern high latitudes could be emitted from the pan-Arctic $\left(>60^{\circ} \mathrm{N}\right)$. For all scenarios, the inverse modeling adjusts total $\mathrm{CH}_{4}$ emissions downward compared to prior emissions. It is possible that $\mathrm{CH}_{4}$ emissions are overestimated by the biogeochemi- 
Table 2. Estimated annual $\mathrm{CH}_{4}$ emissions (units: $\mathrm{Tg} \mathrm{CH}_{4} \mathrm{yr}^{-1}$ ) for TransCom 3 land regions (NAB: North American boreal; NAT: North American temperate; SATr: South American tropical; SAT: South American temperate; NAf: northern Africa; SAf: southern Africa; ErB: Eurasian boreal; ErT: Eurasian temperate; TrA: tropical Asia; Aus: Australasia; and Eur: Europe). The priors are the range of the initial $\mathrm{CH}_{4}$ emissions given by the six scenarios.

\begin{tabular}{lrrrrrrrrr}
\hline Region & Priors & \multicolumn{9}{c}{ Posterior } & & & & $\begin{array}{r}\text { Fraser et } \\
\text { al. }(2013)\end{array}$ & $\begin{array}{r}\text { Alexe et } \\
\text { al. (2015) }\end{array}$ \\
& & & & & & & & \\
\cline { 3 - 8 } & & BERN & CLM4Me & DLEM & ORCHIDEE & SDGVM & WSL & \\
\hline NAB & $7.9-26.0$ & 24.3 & 16.2 & 16.8 & 27.4 & 12.0 & 20.7 & $5.1 \pm 1.1$ & 10.3 \\
NAT & $38.5-59.2$ & 33.2 & 32.8 & 42.8 & 49.2 & 51.2 & 39.7 & $62.5 \pm 4.4$ & 45.6 \\
SATr & $29.6-100.0$ & 43.0 & 60.8 & 31.4 & 61.0 & 62.3 & 42.1 & $49.6 \pm 6.4$ & 71.8 \\
SAT & $29.1-55.8$ & 31.2 & 27.1 & 35.2 & 39.1 & 25.6 & 30.5 & $55.8 \pm 9.5$ & 40.2 \\
NAf & $26.8-31.2$ & 34.0 & 41.3 & 27.9 & 28.0 & 27.7 & 32.0 & $46.9 \pm 7.3$ & 50.6 \\
SAf & $16.0-27.0$ & 18.4 & 16.2 & 19.0 & 24.2 & 15.6 & 18.7 & $36.6 \pm 5.8$ & 42.0 \\
ErB & $11.5-32.7$ & 19.2 & 14.3 & 16.5 & 18.7 & 22.2 & 14.9 & $16.5 \pm 3.8$ & 15.4 \\
ErT & $114.9-133.5$ & 97.0 & 84.9 & 146.1 & 92.7 & 98.3 & 99.8 & $115.9 \pm 7.3$ & 109.6 \\
TrA & $33.1-45.8$ & 47.3 & 51.4 & 35.8 & 33.1 & 36.4 & 45.1 & $43.5 \pm 3.2$ & 76.8 \\
Aus & $5.8-8.3$ & 7.3 & 7.7 & 6.6 & 7.9 & 6.3 & 7.3 & $17.6 \pm 2.7$ & 4.3 \\
Eur & $43.6-53.5$ & 54.9 & 52.2 & 46.4 & 43.5 & 56.5 & 54.1 & $39.6 \pm 3.7$ & 28.9 \\
\hline Wetlands & $121.7-278.1$ & 166.8 & 164.6 & 130.0 & 203.3 & 161.8 & 160.7 & $192.1 \pm 16.1$ & 169 \\
Global & $471.5-627.8$ & 501.0 & 497.7 & 511.5 & 511.0 & 496.4 & 502.9 & $510.6 \pm 18.4$ & 540.5 \\
\hline
\end{tabular}

cal models or double-counted between the wetland and lake models or both. This adjustment could also be explained by the underestimate of $\mathrm{CH}_{4}$ absorption by soils in biogeochemical models due to the lack of high-affinity methanotrophy (Oh et al., 2016).

\subsection{2 $\mathrm{CH}_{4}$ emissions from pan-Arctic lakes}

In contrast to $\mathrm{CH}_{4}$ emissions from pan-Arctic wetlands, $\mathrm{CH}_{4}$ emissions from pan-Arctic lakes at large spatial scales are still largely unknown. Consensus has not been reached yet on how to apply the knowledge learnt from individual lakes to the pan-Arctic scale, because even lakes in a small area could have much different transport pathways (ebullition vs. diffusion), morphology (deep vs. shallow and large vs. small), eutrophication (eutrophic vs. oligotrophic), and carbon source (thermokarst vs. non-thermokarst and yedoma vs. non-yedoma). Because wetlands and lakes, both inundation landscapes, are usually neighboring, it is difficult to use inverse modeling at coarse spatial scales to detect strong $\mathrm{CH}_{4}$ emissions that are emitted solely by lakes. To test whether high-resolution inversions can better represent $\mathrm{CH}_{4}$ emissions from lakes, we conducted a comparison test ("DLEM only") over the east Siberian coastal lowlands (Fig. 1) using the DLEM model and excluding $\mathrm{CH}_{4}$ emissions from lakes. We chose the east Siberian lowlands to test our hypothesis as lakes there occupy $56 \%$ of the water-inundated landscapes i.e., lakes, wetlands, and rivers (Lehner and Döll, 2004) - and a large fraction of lakes in the region are high-flux yedoma lakes (Walter et al., 2006). We chose the DLEM model, considering that the simulated wetland $\mathrm{CH}_{4}$ emissions in this model are weak for the east Siberian lowlands. This design is also aimed to alleviate the impact of one major shortcoming: because there are not sufficient high-quality observations, we optimized the total $\mathrm{CH}_{4}$ emission in each grid cell, and in this manner a fraction of lake emissions could be attributed incorrectly to wetlands or vice versa. The inversion of the DLEM-only scenario is shown in Fig. S5. In comparison to Fig. $4 \mathrm{c}, \mathrm{CH}_{4}$ emissions from the east Siberian coastal lowlands are low in Fig. S5. A further comparison of modelsatellite agreement between the DLEM scenario and this nolake scenario reveals that the agreement improves when lake emissions are considered (see Fig. 6; $p=0.0032838$ at the two-sample $t$ test). It implies that $\mathrm{CH}_{4}$ emissions from regional lakes could be significant. As illustrated above, however, the spatial neighborhood of wetlands and lakes makes it difficult to conduct similar experiments in other areas. Thus we are cautious to claim that $\mathrm{CH}_{4}$ emissions from lakes are ubiquitously strong across the pan-Arctic. Rather, since we used six wetland models that can simulate very different wetland emission distributions at spatial and temporal scales, our estimates of 2.4-14.2 $\mathrm{Tg} \mathrm{CH}_{4} \mathrm{yr}^{-1}$ for lake emissions could be more useful in explaining the range of this source. The lower bound of our estimate is much smaller than the estimate of 7.1-17.3 $\mathrm{Tg} \mathrm{CH}_{4} \mathrm{yr}^{-1}$ by Bastviken et al. (2011) in the use of extensive site-level observations. In contrast, the upper bound of our estimate is within the range. Given the wide span of this estimate, it is difficult to say whether $\mathrm{CH}_{4}$ emissions from pan-Arctic lakes can be significant across the region. 

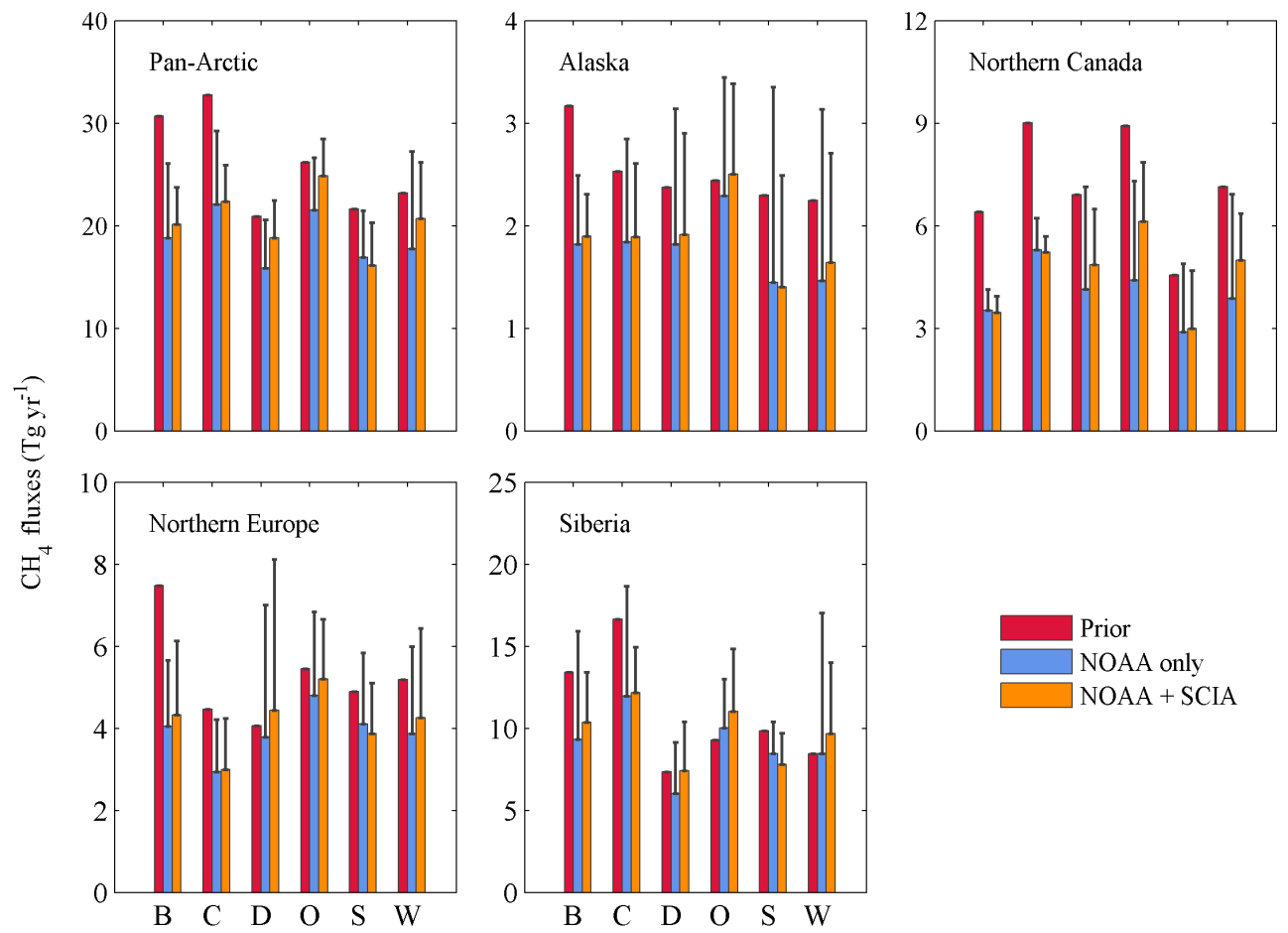

Figure 5. Comparison of prior and posterior pan-Arctic $\mathrm{CH}_{4}$ emissions and their uncertainties. "NOAA only" represents posterior emissions assimilating only surface measurements. "NOAA + SCIA" represents posterior emissions assimilating both surface measurements and satellite retrievals. The uncertainty of prior emissions is $100 \%$. Scenarios are represented by their name initials: "B" for BERN, "C" for CLM4Me, "D" for DLEM, "O" for ORCHIDEE, "S" for SDGVM, and "W" for WSL.

\subsection{3 $\mathrm{CH}_{4}$ emissions from pan-Arctic wetlands}

Arctic tundra is regarded as an important source of $\mathrm{CH}_{4}$ in the northern high latitudes. By using process-based models and atmospheric $\mathrm{CH}_{4}$ observations, McGuire et al. (2012) estimated that Arctic tundra was a source of $25 \mathrm{Tg} \mathrm{CH}_{4} \mathrm{yr}^{-1}$ to the atmosphere during 1990-2006. By using the Transport Model 5 (TM5)-4DVAR inverse model and assimilating SCIAMACHY and NOAA/ESRL observations, Alexe et al. (2015) estimated that $\mathrm{CH}_{4}$ emissions from Arctic wetlands were $18.2 \mathrm{Tg} \mathrm{CH}_{4} \mathrm{yr}^{-1}$ for 2010-2011. A similar estimate of $16 \pm 5 \mathrm{Tg} \mathrm{CH}_{4} \mathrm{yr}^{-1}$ was also made by Bruhwiler et al. (2014) using the CarbonTracker- $\mathrm{CH}_{4}$ assimilation system. Our estimate of 5.5-14.2 $\mathrm{Tg} \mathrm{CH}_{4} \mathrm{yr}^{-1}$ overlaps with the estimate of Bruhwiler et al. (2014) but is much lower than the estimates of Alexe et al. (2015) and McGuire et al. (2012). However, McGuire et al. (2012) did not use complex inverse models, and Alexe et al. (2015) used the coarse-resolution TM54DVAR inverse model. As our global inversions (Table 2) are consistent with the estimate of Alexe et al. (2015), this difference is likely introduced by the use of the nested-grid inverse model. In other words, the nested-grid inverse model reveals some information that could be missed in global coarseresolution inversions. For Siberian wetlands, they could emit much more $\mathrm{CH}_{4}\left(1.6-7.6 \mathrm{Tg} \mathrm{yr}^{-1}\right)$ than any other areas. But the uncertainty of the Siberian emissions is also the largest.
Using the atmospheric $\mathrm{CH}_{4}$ observation data at several sites near Siberian wetlands, Berchet et al. (2015) estimated that $\mathrm{CH}_{4}$ emissions from Siberian wetlands were in the range of 1-13 $\mathrm{Tg} \mathrm{CH}_{4} \mathrm{yr}^{-1}$, wider than our estimated range. In addition, our estimate is also much smaller than the estimate of $21.63 \pm 5.25 \mathrm{Tg} \mathrm{CH}_{4} \mathrm{yr}^{-1}$ by Kim et al. (2012) for annual mean $\mathrm{CH}_{4}$ emissions from Siberian wetlands during 2005 2010. According to our inversions, $\mathrm{CH}_{4}$ emissions from wetlands in Alaska, northern Canada, and northern Europe are $0-1.2,0.4-4.8$, and $0.7-3.6 \mathrm{Tg} \mathrm{CH}_{4} \mathrm{yr}^{-1}$, respectively. For Alaskan wetlands, the total of posterior $\mathrm{CH}_{4}$ emissions is much lower than the inferred value of $4.1 \mathrm{Tg} \mathrm{CH}_{4} \mathrm{yr}^{-1}$ for the Alaskan Yukon River basin during 1986-2005 using the modeling of process-based $\mathrm{CH}_{4}$ biogeochemistry and largescale hydrology (Lu and Zhuang, 2012) and also much lower than the inferred value of $3 \mathrm{Tg} \mathrm{CH}_{4} \mathrm{yr}^{-1}$ for the whole of Alaska (Zhuang et al., 2007). Our estimate of wetland emissions from northern Europe compasses a European-scale estimate of 3.6 $\mathrm{Tg} \mathrm{CH}_{4} \mathrm{yr}^{-1}$ by Saarnio et al. (2009), agreeing with the finding that wetlands in Europe are predominantly located north of $60^{\circ} \mathrm{N}$.

\subsubsection{Evaluation of pan-Arctic $\mathrm{CH}_{4}$ inversions}

As shown in Fig. 7, in most of scenarios, the nested-grid inversions perform much better than both the forward simula- 


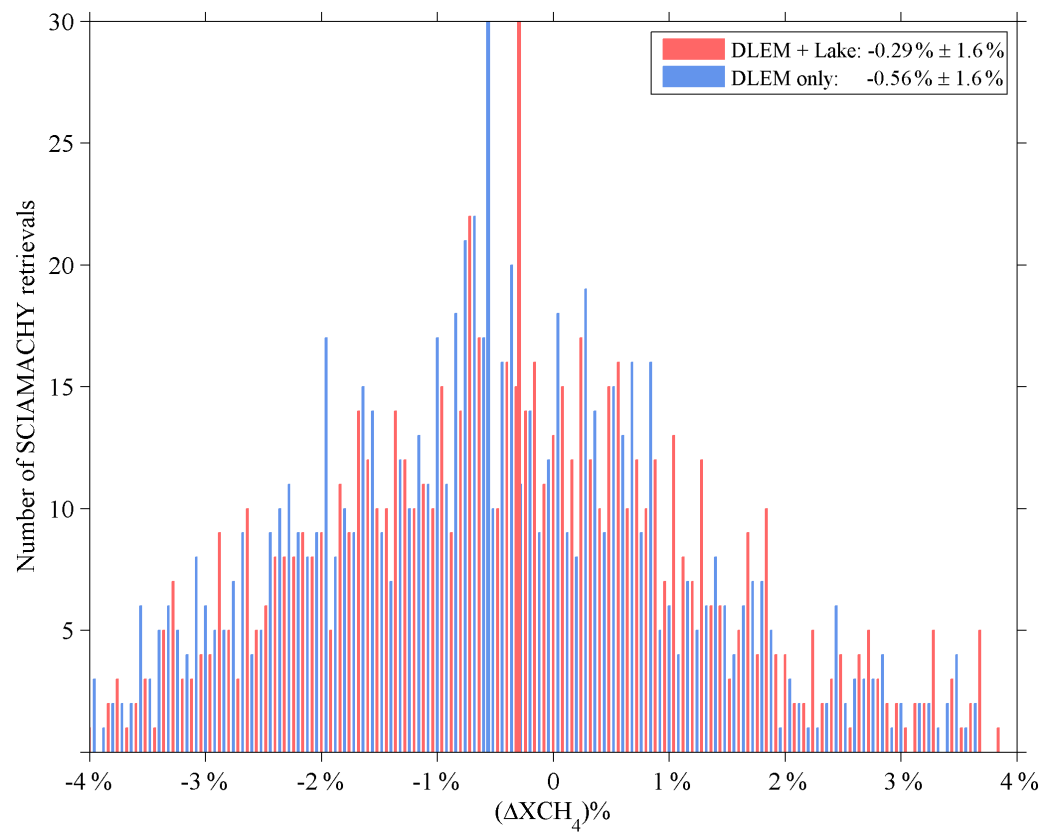

Figure 6. Distribution of the relative difference between the observed and simulated posterior SCIAMACHY column-average mixing ratios. The "DLEM + lake" scenario includes $\mathrm{CH}_{4}$ emissions from both wetlands and lakes, and the "DLEM-only" scenario only includes $\mathrm{CH}_{4}$ emissions from wetlands. Relative difference is calculated as a percentage of absolute differences between GEOS-Chem and SCIAMACHY relative to SCIAMACHY retrievals. Two extending red and blue lines represent the means of the simulation bias under the DLEM + lake scenario and the DLEM-only scenario, respectively.

tions and the global inversions at NOAA/ESRL pan-Arctic flask sites (Fig. 1). For example, for the ORCHIDEE scenario, the nested-grid inversion reduces the model bias by $44 \mathrm{ppb}$ relative to the forward run and by $20 \mathrm{ppb}$ relative to the global inversion. Also, for the SDGVM scenario, it reduces the model bias by $22 \mathrm{ppb}$ relative to the forward run and by $13 \mathrm{ppb}$ relative to the global inversion. But for aircraft $\mathrm{CH}_{4}$ measurements, it is more complex. The nested-grid inversions can reduce the model bias in some scenarios greatly, e.g., the CLM4Me scenario and the SDGVM scenario. But in many cases, they do not perform visibly better than the forward runs and the global inversions. One possible reason is that the root mean square error (RMSE) of aircraft $\mathrm{CH}_{4}$ has already been low, and thus the remaining errors, including the representation error of model diurnal variability, cannot be resolved by our current inversion system. For example, $\mathrm{CH}_{4}$ emissions from Alaska can be well constrained by three NOAA/ESRL surface sites in Alaska (BRW, CBA, and SHM), and the $\mathrm{CH}_{4}$ mixing ratios at the aircraft PFA (Poker Flat, Alaska) site are representative of the interior of Alaska as pointed out in Sweeney et al. (2015). It is also possible that the increase of grid cells in the nested-grid inversions introduced more transport and computation errors.

\subsection{Further discussion}

Both the global and nested-grid inversions indicate that the inverse modeling is more sensitive to different wetland models than prior emission error and data error. Thus, to gain better understandings of the global and pan-Arctic $\mathrm{CH}_{4}$ cycles, it is important to develop more realistic biogeochemical models. Especially from the perspective of inverse modeling, focus should be on improving the spatial and temporal representation of the models rather than emission magnitude.

For the high-resolution inverse modeling, transport and computation errors of the nested-grid CTMs need to be reduced for better performance. These CTMs can also benefit the efforts to assimilate aircraft $\mathrm{CH}_{4}$ measurements. For the purpose of satellite data bias correction, more coordination between satellite missions and aircraft missions is demanded. The treatment of the SCIAMACHY bias could be an important uncertainty source for our estimates, as suggested by Houweling et al. (2014). Future top-down studies could benefit from a more reasonable bias correction method, even for low bias satellite products, e.g., GOSAT (Alexe et al., 2015).

The attribution of $\mathrm{CH}_{4}$ fluxes to spatially overlapped sources, e.g., wetlands and lakes, could be problematic for even high-resolution inversions. Carbon isotope measurements $\left(\delta^{13} \mathrm{CH}_{4}\right)$ are widely used to separate biogenic and geologic $\mathrm{CH}_{4}$ sources (Langenfelds et al., 2002) but are not useful for two biogenic sources with similar carbon isotope 


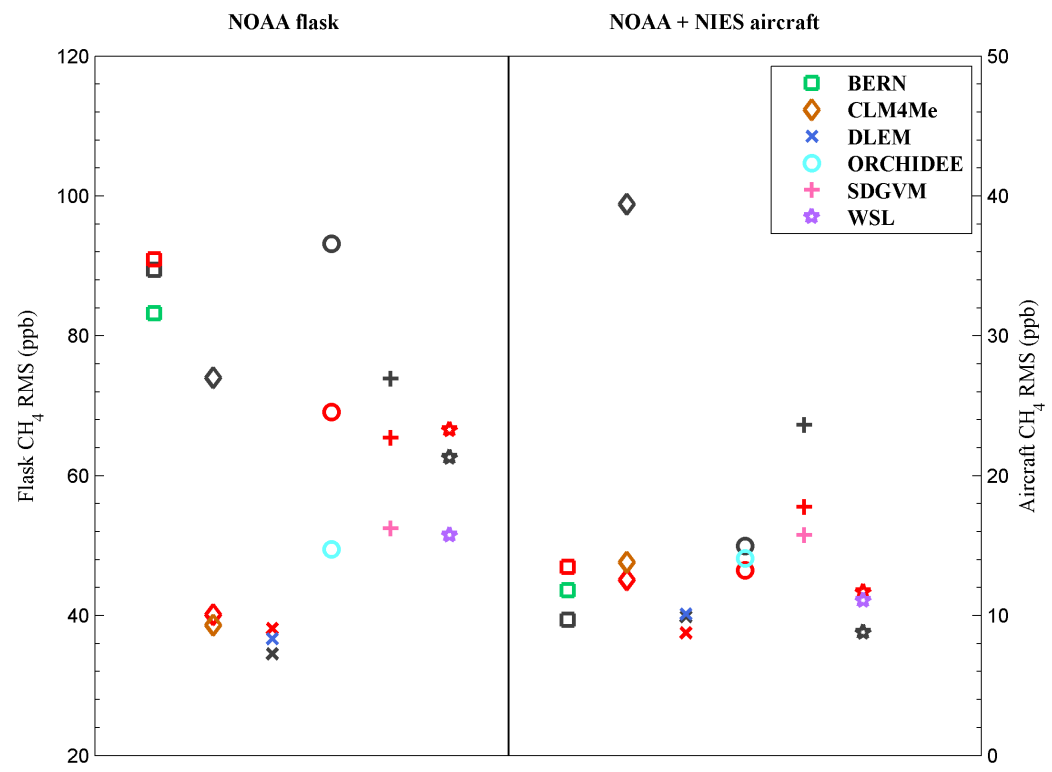

Figure 7. Evaluation of the posterior GEOS-Chem $\mathrm{CH}_{4}$ mole fractions from the pan-Arctic nested-grid inversions with independent data sets from the NOAA flask stations, the NOAA aircraft PFA profiles, and the NIES aircraft Surgut profiles. Black symbols indicate the RMSE of the forward GEOS-Chem runs, and red symbols indicate the RMSE of the global inversions.

ratios (Walter et al., 2008; Fisher et al., 2011). In our study, lake and wetland emissions were simulated separately by different models. This raised the possibility of double-counting emissions of the two sources. A possible solution is to simulate them together in one Earth system model and use a consistent method to identify wetland and lake pixels.

Our nested-grid adjoint model currently does not cover the regions near the North Pole. While it could be rare in the summertime, if air mass is transported across the Arctic Ocean, it may not be represented in the model. In the following studies, we will adapt the advection algorithm for the polar region from the global adjoint model to the nestedgrid model and validate the adaptation. These refinements shall reduce the uncertainty of our estimates. It is also valuable to discuss the integration of other natural $\mathrm{CH}_{4}$ sources found in the pan-Arctic, such as $\mathrm{CH}_{4}$ emission from subsea permafrost of the East Siberian Shelf (Berchet et al., 2016; Thornton et al., 2016). As shown in Fig. 1, our inverse modeling assimilated few high-precision surface $\mathrm{CH}_{4}$ measurements in Siberia and northern Canada. Since some efforts have already been made by different teams to measure atmospheric $\mathrm{CH}_{4}$ routinely in Siberia (e.g., the JapanRussia Siberian Tall Tower Inland Observation Network(JRSTATION) by NIES, the Zotino Tall Tower Observatory by the Max Planck Institute for Biogeochemistry (MPI-BGC), and the Tiksi site by the Finnish Meteorological Institute) and in the North American Arctic (e.g., the Behchoko site by Environment Canada), we would like to take advantage of these measurements to further improve our inversion results and re-evaluate the gains of using satellite data in our future studies.

\section{Conclusions}

In this study, we used a high-resolution nested-grid adjoint model in the pan-Arctic domain to constrain $\mathrm{CH}_{4}$ emissions from pan-Arctic wetlands, lakes, and anthropogenic sources. The sensitivity of the method to different prior wetland $\mathrm{CH}_{4}$ fluxes was tested. When assimilating both NOAA/ESRL measurements and SCIAMACHY retrievals, we estimated that in 2005 the total of global $\mathrm{CH}_{4}$ emissions was in the range of 496.4-511.5 $\mathrm{Tg} \mathrm{CH}_{4} \mathrm{yr}^{-1}$, with wetlands contributing 130.0-203.3 Tg $\mathrm{CH}_{4} \mathrm{yr}^{-1}$. Both of these estimates are consistent with some widely accepted expert assessments. The estimated $\mathrm{CH}_{4}$ emissions in the pan-Arctic were in the range of $11.9-28.5 \mathrm{Tg} \mathrm{yr}^{-1}$, with wetland and lake emissions ranging from 5.5 to $14.2 \mathrm{Tg} \mathrm{yr}^{-1}$ and from 2.4 to 14.2 $\mathrm{Tg} \mathrm{yr}^{-1}$, respectively. The largest $\mathrm{CH}_{4}$ emissions in the pan-Arctic are from Siberian wetlands and lakes. The study demonstrates that the assimilation of satellite retrievals can reduce the uncertainty of the nested-grid inversions. Evaluation with independent data sets shows that the nested inversions can better improve the representation of $\mathrm{CH}_{4}$ mixing ratios in the lower boundary layer rather than the top boundary layer and free troposphere. 


\section{Data availability}

SCIAMACHY retrievals are available at http: //www.temis.nl/climate/methane/methane_month_scia.php. NOAA/ESRL surface and aircraft observations are available at ftp://aftp.cmdl.noaa.gov/data/trace_gases/ch4/ flask/surface/ and http://www.esrl.noaa.gov/gmd/ccgg/ aircraft/data.html, respectively. NASA/ARCTAS aircraft observations are available at ftp://ftp-air.larc.nasa.gov/ pub/ARCTAS/DC8_AIRCRAFT/DISKIN.GLENN/. NIES aircraft observations, prior lake $\mathrm{CH}_{4}$ emissions, and all model-optimized $\mathrm{CH}_{4}$ emissions are available upon request.

\section{The Supplement related to this article is available online at doi:10.5194/acp-16-12649-2016-supplement.}

Acknowledgements. We would like to thank the two anonymous reviewers for their thorough and constructive reviews. Many thanks are given to the WETCHIMP investigators for making their simulations of wetland methane emissions available. We appreciate the help from Guang-Dih Lei and Bhagirath M. Trivedi at NASA and Robert Yantosca at Harvard for processing nestedgrid GOES-5 met data, and the help from Christoph A. Keller at Harvard for processing nested-grid emission data by HEMCO. This study is supported through projects funded to Qianlai Zhuang by the NASA Land Use and Land Cover Change Program (NASA-NNX09AI26G), the Department of Energy (DOE) (DE-FG02-08ER64599), the NSF Division of Information and Intelligent Systems (NSF-1028291), and the NSF Carbon and Water in the Earth Program (NSF-0630319). This research is also in part supported by the Director, Office of Science, Office of Biological and Environmental Research of the US Department of Energy under contract no. DE-AC02-05CH11231 as part of their Earth System Modeling Program. Daven K. Henze acknowledges NOAA grant no. NA14OAR4310136. Alexander J. Turner was supported by a DOE Computational Science Graduate Fellowship (CSGF). The supercomputing resource is provided by the Rosen Center for Advanced Computing at Purdue University.

Edited by: M. Heimann

Reviewed by: two anonymous referees

\section{References}

Alexe, M., Bergamaschi, P., Segers, A., Detmers, R., Butz, A., Hasekamp, O., Guerlet, S., Parker, R., Boesch, H., Frankenberg, C., Scheepmaker, R. A., Dlugokencky, E., Sweeney, C., Wofsy, S. C., and Kort, E. A.: Inverse modeling of $\mathrm{CH}_{4}$ emissions for 2010-2011 using different satellite retrieval products from GOSAT and SCIAMACHY, Atmos. Chem. Phys., 15, 113133, doi:10.5194/acp-15-113-2015, 2015.

Aydin, M., Verhulst, K. R., Saltzman, E. S., Battle, M. O., Montzka, S. A, Blake, D. R., Tang, Q., and Prather, M. J.: Recent decreases in fossil-fuel emissions of ethane and methane derived from firn air, Nature, 476, 198-201, 2011.

Bastviken, D., Tranvik, L., Downing, J., Crill, P. M., and EnrichPrast, A.: Freshwater methane emissions offset the continental carbon sink, Science, 331, 50-50, 2011.

Berchet, A., Pison, I., Chevallier, F., Paris, J.-D., Bousquet, P., Bonne, J.-L., Arshinov, M. Y., Belan, B. D., Cressot, C., Davydov, D. K., Dlugokencky, E. J., Fofonov, A. V., Galanin, A., Lavrič, J., Machida, T., Parker, R., Sasakawa, M., Spahni, R., Stocker, B. D., and Winderlich, J.: Natural and anthropogenic methane fluxes in Eurasia: a meso-scale quantification by generalized atmospheric inversion, Biogeosciences, 12, 5393-5414, doi:10.5194/bg-12-5393-2015, 2015.

Berchet, A., Bousquet, P., Pison, I., Locatelli, R., Chevallier, F., Paris, J.-D., Dlugokencky, E. J., Laurila, T., Hatakka, J., Viisanen, Y., Worthy, D. E. J., Nisbet, E. G., Fisher, R. E., France, J. L., Lowry, D., and Ivakhov, V.: Atmospheric constraints on the methane emissions from the East Siberian Shelf, Atmos. Chem. Phys., 16, 4147-4157, doi:10.5194/acp-16-4147-2016, 2016.

Bergamaschi, P., Krol, M., Dentener, F., Vermeulen, A., Meinhardt, F., Graul, R., Ramonet, M., Peters, W., and Dlugokencky, E. J.: Inverse modelling of national and European $\mathrm{CH}_{4}$ emissions using the atmospheric zoom model TM5, Atmos. Chem. Phys., 5, 2431-2460, doi:10.5194/acp-5-2431-2005, 2005.

Bergamaschi, P., Frankenberg, C., Meirink, J. F., Krol, M., Dentener, F., Wagner, T., Platt, U., Kaplan, J. O., Körner, S., Heimann, M., Dlugokencky, E. J., and Goede, A.: Satellite chartography of atmospheric methane from SCIAMACHY on board ENVISAT: 2. Evaluation based on inverse model simulations, J. Geophys. Res., 112, D02304, doi:10.1029/2006JD007268, 2007.

Bergamaschi, P., Frankenberg, C., Meirink, J. F., Krol, M., Villani, M. G., Houweling, S., Dentener, F., Dlugokencky, E. J., Miller, J. B., Gatti, L. V., Engel, A., and Levin, I.: Inverse modeling of global and regional $\mathrm{CH} 4$ emissions using SCIAMACHY satellite retrievals, J. Geophys. Res., 114, D22301, doi:10.1029/2009JD012287, 2009.

Bergamaschi, P., Houweling, S., Segers, A., Krol, M., Frankenberg, C., Scheepmaker, R. A., Dlugokencky, E., Wofsy, S. C., Kort, E. a., Sweeney, C., Schuck, T., Brenninkmeijer, C., Chen, H., Beck, V., and Gerbig, C.: Atmospheric $\mathrm{CH}_{4}$ in the first decade of the 21 st century: Inverse modeling analysis using SCIAMACHY satellite retrievals and NOAA surface measurements, J. Geophys. Res.-Atmos., 118, 1-20, 2013.

Bey, I., Jacob, D. J., Yantosca, R. M., Logan, J. A., Field, B. D., Fiore, A. M., Li, Q., Liu, H. Y., Mickley, L. J., and Schultz, M. G.: Global modeling of tropospheric chemistry with assimilated meteorology: model description and evaluation, J. Geophys. Res., 106, 23073-23095, 2001.

Bloom, A. A., Palmer, P. I., Fraser, A., Reay, D. S., and Frankenberg, C.: Large-Scale Controls of Methanogenesis Inferred from Methane and Gravity Spaceborne Data, Science, 327, 322-325, 2010.

Bousquet, P., Ciais, P., Miller, J. B., Dlugokencky, E. J., Hauglustaine, D. A, Prigent, C., Van der Werf, G. R., Peylin, P., Brunke, E.-G., Carouge, C., Langenfelds, R. L., Lathière, J., Papa, F., Ramonet, M., Schmidt, M., Steele, L. P., Tyler, S. C., and White, J.: Contribution of anthropogenic and natural sources to atmospheric methane variability, Nature, 443, 439-443, 2006. 
Bousserez, N., Henze, D. K., Perkins, A., Bowman, K. W., Lee, M., Liu, J., Deng, F., and Jones, D. B. A.: Improved analysiserror covariance matrix for high-dimensional variational inversions: application to source estimation using a 3D atmospheric transport model, Q. J. R. Meteorol. Soc., 141, 1479-1974, doi:10.1002/qj.2495, 2015.

Bruhwiler, L. M., Dlugokencky, E., Masarie, K., Ishizawa, M., Andrews, A., Miller, J., Sweeney, C., Tans, P., and Worthy, D.: CarbonTracker- $\mathrm{CH}_{4}$ : an assimilation system for estimating emissions of atmospheric methane, Atmos. Chem. Phys., 14, 82698293, doi:10.5194/acp-14-8269-2014, 2014.

Butz, A., Hasekamp, O. P., Frankenberg, C., Vidot, J., and Aben, I.: $\mathrm{CH}_{4}$ retrievals from space-based solar backscatter measurements: Performance evaluation against simulated aerosol and cirrus loaded scenes, J. Geophys. Res. Atmos., 115, D24302, doi:10.1029/2010JD014514, 2010.

Cressot, C., Chevallier, F., Bousquet, P., Crevoisier, C., Dlugokencky, E. J., Fortems-Cheiney, A., Frankenberg, C., Parker, R., Pison, I., Scheepmaker, R. A., Montzka, S. A., Krummel, P. B., Steele, L. P., and Langenfelds, R. L.: On the consistency between global and regional methane emissions inferred from SCIAMACHY, TANSO-FTS, IASI and surface measurements, Atmos. Chem. Phys., 14, 577-592, doi:10.5194/acp-14-577-2014, 2014.

Deng, F., Jones, D. B. A., Henze, D. K., Bousserez, N., Bowman, K. W., Fisher, J. B., Nassar, R., O’Dell, C., Wunch, D., Wennberg, P. O., Kort, E. A., Wofsy, S. C., Blumenstock, T., Deutscher, N. M., Griffith, D. W. T., Hase, F., Heikkinen, P., Sherlock, V., Strong, K., Sussmann, R., and Warneke, T.: Inferring regional sources and sinks of atmospheric $\mathrm{CO}_{2}$ from GOSAT $\mathrm{XCO}_{2}$ data, Atmos. Chem. Phys., 14, 3703-3727, doi:10.5194/acp-14-37032014, 2014.

Denman, K. L., Brasseur, G., Chidthaisong, A., Ciais, P., Cox, P. M., Dickinson, R. E., Hauglustaine, D., Heinze, C., Holland, E., Jacob, D., Lohmann, U., Ramachandran, S., da Silva Dias, P. L., Wofsy, S. C., and Zhang, X.: Couplings Between Changes in the Climate System and Biogeochemistry, in: Climate Change 2007: The Physical Science Basis. Contribution of Working Group I to the Fourth Assessment Report of the Intergovernmental Panel on Climate Change, edited by: Solomon, S., Qin, D., Manning, M., Chen, Z., Marquis, M., Averyt, K. B., Tignor, M., and Miller, H. L., Cambridge University Press, Cambridge, United Kingdom and New York, NY, USA, 2007.

Dlugokencky, E., Masarie, K., and Lang, P.: Continuing decline in the growth rate of atmospheric methane burden, Nature, 393, 447-450, 1998.

Dlugokencky, E. J., Houweling, S., Bruhwiler, L., Masarie, K. A., Lang, P. M., Miller, J. B., and Tans, P. P.: Atmospheric methane levels off: Temporary pause or a new steady-state?, Geophys. Res. Lett., 30, 8028, doi:10.1029/2003GL018126, 2003.

Dlugokencky, E. J., Myers, R. C., Lang, P. M., Masarie, K. A., Crotwell, A. M., Thoning, K. W., Hall, B. D., Elkins, J. W., and Steele, L. P.: Conversion of NOAA atmospheric dry-air $\mathrm{CH}_{4}$ mole fractions to a gravimetrically prepared standard scale, J. Geophys. Res.-Atmos., 110, D18306, doi:10.1029/2005JD006035, 2005.

Dlugokencky, E. J., Bruhwiler, L., White, J. W. C., Emmons, L. K., Novelli, P. C., Montzka, S. A., Masarie, K. A., Lang, P. M., Crotwell, A. M., Miller, J. B., and Gatti, L. V.: Observational constraints on recent increases in the atmospheric $\mathrm{CH}_{4}$ burden,
Geophys. Res. Lett., 36, L18803, doi:10.1029/2009GL039780, 2009.

Dlugokencky, E. J., Lang, P. M., Crotwell, A. M., Masarie, K. A., and Crotwell M. J.: Atmospheric Methane Dry Air Mole Fractions from the NOAA ESRL Carbon Cycle Cooperative Global Air Sampling Network, 1983-2013, Version: 2014-0624, available at: ftp://aftp.cmdl.noaa.gov/data/trace_gases/ch4/ flask/surface/ (last access: 9 June 2015), 2014.

Enting, I. G.: Inverse problems in atmospheric constituent transport, Cambridge University Press, 2002.

Etheridge, D. M., Steele, L. P., Francey, R. J., and Langenfelds, R. L.: Atmospheric methane between 1000 A.D. and present: Evidence of anthropogenic emissions and climatic variability, J. Geophys. Res., 103, 15979-15993, 1998.

European Commission, Joint Research Centre/Netherlands Environmental Assessment Agency: Emission Database for Global Atmospheric Research (EDGAR), release version 4.0., available at: http://edgar.jrc.ec.europa.eu (last access: 11 June 2015), 2009.

Fiore, A. M., Horowitz, L. W., Dlugokencky, E. J., and West, J. J.: Impact of meteorology and emissions on methane trends, 1990-2004, Geophys. Res. Lett., 33, L12809, doi:10.1029/2006GL026199, 2006.

Fisher, R. E., Sriskantharajah, S., Lowry, D., Lanoisellé, M., Fowler, C. M. R., James, R. H., Hermansen, O., Lund Myhre, C., Stohl, A., Greinert, J., Nisbet-Jones, P. B. R., Mienert, J., and Nisbet, E. G.: Arctic methane sources: Isotopic evidence for atmospheric inputs, Geophys. Res. Lett., 38, L21803, doi:10.1029/2011GL049319, 2011.

Frankenberg, C., Meirink, J. F., Bergamaschi, P., Goede, A. P. H., Heimann, M., Kröner, S., Platt, U., van Weele, M., and Wagner, T.: Satellite chartography of atmospheric methane from SCIAMACHY on board ENVISAT: Analysis of the years 2003 and 2004, J. Geophys. Res., 111, D07303, doi:10.1029/2005JD006235, 2006.

Frankenberg, C., Bergamaschi, P., Butz, A., Houweling, S., Meirink, J. F., Notholt, J., Petersen, A. K., Schrijver, H., Warneke, T., and Aben, I.: Tropical methane emissions: A revised view from SCIAMACHY onboard ENVISAT, Geophys. Res. Lett., 35, L15811, doi:10.1029/2008GL034300, 2008.

Frankenberg, C., Aben, I., Bergamaschi, P., Dlugokencky, E. J., van Hees, R., Houweling, S., van der Meer, P., Snel, R., and Tol, P.: Global column-averaged methane mixing ratios from 2003 to 2009 as derived from SCIAMACHY: Trends and variability, J. Geophys. Res., 116, D02304, doi:10.1029/2010JD014849, 2011.

Fraser, A., Palmer, P. I., Feng, L., Boesch, H., Cogan, A., Parker, R., Dlugokencky, E. J., Fraser, P. J., Krummel, P. B., Langenfelds, R. L., O’Doherty, S., Prinn, R. G., Steele, L. P., van der Schoot, M., and Weiss, R. F.: Estimating regional methane surface fluxes: the relative importance of surface and GOSAT mole fraction measurements, Atmos. Chem. Phys., 13, 5697-5713, doi:10.5194/acp-13-5697-2013, 2013.

Fung, I., John, J., Lerner, J., Matthews, E., Prather, M., Steele, L. P., and Fraser, P. J.: Three-dimensional model synthesis of the global methane cycle, J. Geophys. Res., 96, 13033-13065, 1991.

GLOBALVIEW-CH4: Cooperative Atmospheric Data Integration Project - Methane, CD-ROM, NOAA ESRL, Boulder, Colorado, available at: ftp://ftp.cmdl.noaa.gov (last access: $19 \mathrm{Au}-$ gust 2015), Path: products/globalview/ch4, 2009. 
Gurney, K. R., Law, R. M., Denning, A. S., Rayner, P. J., Baker, D., Bousquet, P., Bruhwiler, L., Chen, Y.-H., Ciais, P., Fan, S., Fung, I. Y., Gloor, M., Heimann, M., Higuchi, K., John, J., Maki, T., Maksyutov, S., Masarie, K., Peylin, P., Prather, M., Pak, B. C., Randerson, J., Sarmiento, J., Taguchi, S., Takahashi, T., and Yuen, C.-W.: Towards robust regional estimates of $\mathrm{CO}_{2}$ sources and sinks using atmospheric transport models, Nature, 415, 626630, 2002.

Heald, C. L., Jacob, D. J., Jones, D. B. A., Palmer, P. I., Logan, J. A., Streets, D. G., Sachse, G. W., Gille, J. C., Hoffman, R. N., and Nehrkorn, T.: Comparative inverse analysis of satellite (MOPITT) and aircraft (TRACE-P) observations to estimate Asian sources of carbon monoxide, J. Geophys. Res., 109, D23306, doi:10.1029/2004JD005185, 2004.

Henze, D. K., Hakami, A., and Seinfeld, J. H.: Development of the adjoint of GEOS-Chem, Atmos. Chem. Phys., 7, 2413-2433, doi:10.5194/acp-7-2413-2007, 2007.

Houweling, S., Krol, M., Bergamaschi, P., Frankenberg, C., Dlugokencky, E. J., Morino, I., Notholt, J., Sherlock, V., Wunch, D., Beck, V., Gerbig, C., Chen, H., Kort, E. a., Röckmann, T., and Aben, I.: A multi-year methane inversion using SCIAMACHY, accounting for systematic errors using TCCON measurements, Atmos. Chem. Phys., 14, 3991-4012, doi:10.5194/acp-14-39912014, 2014.

Jacob, D. J., Crawford, J. H., Maring, H., Clarke, A. D., Dibb, J. E., Emmons, L. K., Ferrare, R. A., Hostetler, C. A., Russell, P. B., Singh, H. B., Thompson, A. M., Shaw, G. E., McCauley, E., Pederson, J. R., and Fisher, J. A.: The Arctic Research of the Composition of the Troposphere from Aircraft and Satellites (ARCTAS) mission: design, execution, and first results, Atmos. Chem. Phys., 10, 5191-5212, doi:10.5194/acp-10-5191-2010, 2010.

Jiang, Z., Jones, D. B. A., Kopacz, M., Liu, J., Henze, D. K., and Heald, C.: Quantifying the impact of model errors on top-down estimates of carbon monoxide emissions using satellite observations, J. Geophys. Res., 116, D15306, doi:10.1029/2010JD015282, 2011.

Kai, F. M., Tyler, S. C., Randerson, J. T., and Blake, D. R.: Reduced methane growth rate explained by decreased Northern Hemisphere microbial sources, Nature, 476, 194-197, 2011.

Kaminski, T. and Heimann, M.: Inverse modeling of atmospheric carbon dioxide fluxes, Science, 294, 259-259, 2001.

Keller, C. A., Long, M. S., Yantosca, R. M., Da Silva, A. M., Pawson, S., and Jacob, D. J.: HEMCO v1.0: a versatile, ESMFcompliant component for calculating emissions in atmospheric models, Geosci. Model Dev., 7, 1409-1417, doi:10.5194/gmd-71409-2014, 2014.

Khalil, M. A. K., Butenhoff, C. L., and Rasmussen, R. A.: Atmospheric methane: trends and cycles of sources and sinks, Environ. Sci. Technol., 41, 2131-2137, 2007.

Kim, H., Machida, T., Sasakawa, M., Belikov, D., Saeki, T., Ito, A., and Maksyutov, S.: Recent variation of Siberian $\mathrm{CH}_{4}$ fluxes estimated from atmospheric observations of $\mathrm{CH}_{4}$, AGU Fall Meeting Abstracts, 1, GC24A-08, 2012.

Kirschke, S., Bousquet, P., Ciais, P., Saunois, M., Canadell, J. G., Dlugokencky, E. J., Bergamaschi, P., Bergmann, D., Blake, D. R., Bruhwiler, L., Cameron-Smith, P., Castaldi, S., Chevallier, F., Feng, L., Fraser, A., Heimann, M., Hodson, E. L., Houweling, S., Josse, B., Fraser, P. J., Krummel, P. B., Lamarque, J.-F., Langenfelds, R. L., Le Quéré, C., Naik, V., O’Doherty, S., Palmer, P.
I., Pison, I., Plummer, D., Poulter, B., Prinn, R. G., Rigby, M., Ringeval, B., Santini, M., Schmidt, M., Shindell, D. T., Simpson, I. J., Spahni, R., Steele, L. P., Strode, S. A., Sudo, K., Szopa, S., van der Werf, G. R., Voulgarakis, A., van Weele, M., Weiss, R. F., Williams, J. E., and Zeng, G.: Three decades of global methane sources and sinks, Nat. Geosci., 6, 813-823, 2013.

Kopacz, M., Jacob, D. J., Henze, D. K., Heald, C. L., Streets, D. G., and Zhang, Q.: Comparison of adjoint and analytical Bayesian inversion methods for constraining Asian sources of carbon monoxide using satellite (MOPITT) measurements of CO columns, J. Geophys. Res., 114, D04305, doi:10.1029/2007JD009264, 2009.

Kort, E. A., Wofsy, S. C., Daube, B. C., Diao, M., Elkins, J. W., Gao, R. S., Hintsa, E. J., Hurst, D. F., Jimenez, R., Moore, F. L., Spackman, J. R., and Zondlo, M. A.: Atmospheric observations of Arctic Ocean methane emissions up to $82^{\circ}$ north, Nat. Geosci., 5, 318-321, doi:10.1038/ngeo1452, 2012.

Koven, C. D., Ringeval, B., Friedlingstein, P., Ciais, P., Cadule, P., Khvorostyanov, D., Krinner, G., and Tarnocai, C.: Permafrost carbon-climate feedbacks accelerate global warming, P. Natl Acad. Sci., 108, 14769-14774, 2011.

Langenfelds, R. L., Francey, R. J., Pak, B. C., Steele, L. P., Lloyd, J., Trudinger, C. M., and Allison, C. E.: Interannual growth rate variations of atmospheric $\mathrm{CO}_{2}$ and its $\delta^{13} \mathrm{C}, \mathrm{H}_{2}, \mathrm{CH}_{4}$, and $\mathrm{CO}$ between 1992 and 1999 linked to biomass burning, Global Biogeochem. Cy., 16, 1048, doi:10.1029/2001GB001466, 2002.

Lehner, B. and Döll, P.: Development and validation of a global database of lakes, reservoirs and wetlands, J. Hydrol., 296, 1-22, 2004.

Levin, I., Veidt, C., Vaughn, B. H., Brailsford, G., Bromley, T., Heinz, R., Lowe, D., Miller, J. B., Poß, C., and White, J. W. C.: No inter-hemispheric $\delta^{13} \mathrm{CH}_{4}$ trend observed, Nature, 486, E3-E4, doi:10.1038/nature11175, 2012.

Lin, S.-J. and Rood, R. B.: Multidimensional Flux-Form SemiLagrangian Transport Schemes, Mon. Weather Rev., 124, 20462070, 1996.

Lu, X. and Zhuang, Q.: Modeling methane emissions from the Alaskan Yukon River basin, 1986-2005, by coupling a largescale hydrological model and a process-based methane model, J. Geophys. Res., 117, G02010, doi:10.1029/2011JG001843, 2012.

Machida, T., Nakazawa, T., Muksyutov, S., Tohjima, Y., Takahashi, Y.,Watai, T., Vinnichenko, N., Panchenko, M., Arshinov, M., Fedoseev, N., and Inoue, G.: Temporal and spatial variations of atmospheric $\mathrm{CO}_{2}$ mixing ratio over Siberia, paper presented at the Sixth International $\mathrm{CO}_{2}$ Conference, Sendai, Japan, 1-5, 2001.

McGuire, A. D., Christensen, T. R., Hayes, D., Heroult, A., Euskirchen, E., Kimball, J. S., Koven, C., Lafleur, P., Miller, P. A., Oechel, W., Peylin, P., Williams, M., and Yi, Y.: An assessment of the carbon balance of Arctic tundra: comparisons among observations, process models, and atmospheric inversions, Biogeosciences, 9, 3185-3204, doi:10.5194/bg-9-3185-2012, 2012.

Meirink, J. F., Bergamaschi, P., and Krol, M. C.: Fourdimensional variational data assimilation for inverse modelling of atmospheric methane emissions: method and comparison with synthesis inversion, Atmos. Chem. Phys., 8, 6341-6353, doi:10.5194/acp-8-6341-2008, 2008.

Melton, J. R., Wania, R., Hodson, E. L., Poulter, B., Ringeval, B., Spahni, R., Bohn, T., Avis, C. A., Beerling, D. J., Chen, G., Eliseev, A. V., Denisov, S. N., Hopcroft, P. O., Lettenmaier, D. 
P., Riley, W. J., Singarayer, J. S., Subin, Z. M., Tian, H., Zürcher, S., Brovkin, V., van Bodegom, P. M., Kleinen, T., Yu, Z. C., and Kaplan, J. O.: Present state of global wetland extent and wetland methane modelling: conclusions from a model intercomparison project (WETCHIMP), Biogeosciences, 10, 753788, doi:10.5194/bg-10-753-2013, 2013.

Meng, L., Paudel, R., Hess, P. G. M., and Mahowald, N. M.: Seasonal and interannual variability in wetland methane emissions simulated by CLM4Me' and CAM-chem and comparisons to observations of concentrations, Biogeosciences, 12, 4029-4049, doi:10.5194/bg-12-4029-2015, 2015.

Miller, S. M., Wofsy, S. C., Michalak, A. M., Kort, E. A., Andrews, A. E., Biraud, S. C., Dlugokencky, E. J., Eluszkiewicz, J., Fischer, M. L., Janssens-Maenhout, G., Miller, B. R., Miller, J. B., Montzka, S. A., Nehrkorn, T., and Sweeney, C.: Anthropogenic emissions of methane in the United States, P. Natl. Acad. Sci., 110, 20018-20022, 2013.

Miller, S. M., Worthy, D. E. J., Michalak, A. M., Wofsy, S. C., Kort, E. A., Havice, T. C., Andrews, A. E., Dlugokencky, E. J., Kaplan, J. O., Levi, P. J., Tian, H., and Zhang, B.: Observational constraints on the distribution, seasonality, and environmental predictors of North American boreal methane emissions, Global Biogeochem. Cy., 28, 146-160, 2014.

Miyazaki, K., Patra, P. K., Takigawa, M., Iwasaki, T., and Nakazawa, T.: Global-scale transport of carbon dioxide in the troposphere, J. Geophys. Res., 113, D15301, doi:10.1029/2007JD009557, 2008.

Monteil, G., Houweling, S., Butz, A., Guerlet, S., Schepers, D., Hasekamp, O., Frankenberg, C., Scheepmaker, R., Aben, I., and Röckmann, T.: Comparison of $\mathrm{CH}_{4}$ inversions based on 15 months of GOSAT and SCIAMACHY observations, J. Geophys. Res. Atmos., 118, 11807-11823, 2013.

Murray, L. T., Jacob, D. J., Logan, J. A., Hudman, R. C., and Koshak, W. J.: Optimized regional and interannual variability of lightning in a global chemical transport model constrained by LIS/OTD satellite data, J. Geophys. Res., 117, D20307, doi:10.1029/2012JD017934, 2012.

Myhre, G., Shindell, D., Bréon, F.-M., Collins, W., Fuglestvedt, J., Huang, J., Koch, D., Lamarque, J.-F., Lee, D., Mendoza, B., Nakajima, T., Robock, A., Stephens, G., Takemura, T., and Zhang, H.: Anthropogenic and natural radiative forcing, in: Climate Change 2013: the Physical Science Basis, contribution of Working Group I to the Fifth Assessment Report of the Intergovernmental Panel on Climate Change, edited by: Stocker, T. F., Qin, D., Plattner, G.-K., Tignor, M., Allen, S. K., Boschung, J., Nauels, A., Xia, Y., Bex, V., and Midgley, P. M., Cambridge University Press, Cambridge, UK and New York, NY, USA, 2013.

Myhre, C. L., Ferré, B., Platt, S. M., Silyakova, A., Hermansen, O., Allen, G., Pisso, I., Schmidbauer, N., Stohl, A., Pitt, J., Jansson, P., Greinert, J., Percival, C., Fjaeraa, A. M., O'Shea, S., Gallagher, M., Le Breton, M., Bower, K., Bauguitte, S., Dalsøren, S., Vadakkepuliyambatta, S., Fisher, R. E., Nisbet, E. G., Lowry, D., Myhre, G., Pyle, J., Cain, M., and Mienert, J.: Extensive release of methane from Arctic seabed west of Svalbard during summer 2014 does not influence the atmosphere, Geophys. Res. Lett., 43, 4624-4631, 2016.

Nisbet, E. G., Dlugokencky, E. J., and Bousquet, P.: Methane on the Rise-Again, Science, 343, 493-495, 2014.
Oh, Y., Stackhouse, B., Lau, M. C. Y., Xu, X., Trugman, A. T., Moch, J., Onstott, T. C., Jørgensen, C. J., Ludovica, D., Elberling, B., Emmerton, C. A., St. Louis, V. L., and Medvigy, D.: A scalable model explaining methane consumption in arctic mineral soils, Geophys. Res. Lett., 43, 5143-5150, 2016.

Park, R. J., Jacob, D. J., Field, B. D., Yantosca, R. M., and Chin, M.: Natural and transboundary pollution influences on sulfate-nitrate-ammonium aerosols in the United States: Implications for policy, J. Geophys. Res., 109, D15204, doi:10.1029/2003JD004473, 2004.

Parker, R., Boesch, H., Cogan, A., Fraser, A., Feng, L., Palmer, P. I., Messerschmidt, J., Deutscher, N., Griffith, D. W. T., Notholt, J., Wennberg, P. O., and Wunch, D.: Methane observations from the Greenhouse Gases Observing SATellite: Comparison to groundbased TCCON data and model calculations, Geophys. Res. Lett., 38, L15807, doi:10.1029/2011GL047871, 2011.

Peng, S. S., Piao, S. L., Bousquet, P., Ciais, P., Li, B. G., Lin, X., Tao, S., Wang, Z. P., Zhang, Y., and Zhou, F.: Inventory of anthropogenic methane emissions in Mainland China from 1980 to 2010, Atmos. Chem. Phys. Discuss., doi:10.5194/acp-2016-139, in review, 2016.

Pickett-Heaps, C. A., Jacob, D. J., Wecht, K. J., Kort, E. A., Wofsy, S. C., Diskin, G. S., Worthy, D. E. J., Kaplan, J. O., Bey, I., and Drevet, J.: Magnitude of seasonality of wetland methane emissions from the Hudson Bay Lowlands (Canada), Atmos. Chem. Phys., 11, 3773-3779, doi:10.5194/acp-11-3773-2011, 2011.

Prather, M. J., Holmes, C. D., and Hsu, J.: Reactive greenhouse gas scenarios: systematic exploration of uncertainties and the role of atmospheric chemistry, Geophys. Res. Lett., 39, L09803, doi:10.1029/2012g1051440, 2012.

Rigby, M., Prinn, R. G., Fraser, P. J., Simmonds, P. G., Langenfelds, R. L., Huang, J., Cunnold, D. M., Steele, L. P., Krummel, P. B., Weiss, R. F., O’Doherty, S., Salameh, P. K., Wang, H. J., Harth, C. M., Mühle, J., and Porter, L. W.: Renewed growth of atmospheric methane, Geophys. Res. Lett., 35, L22805, doi:10.1029/2008GL036037, 2008.

Rodgers, C. D.: Inverse Methods for Atmospheric Sounding: Theory and Practice, Vol. 2, edited by: Rodgers, C. D., World Scientific Publishing Co. Pte. Ltd., Singapore, 2000.

Saarnio, S., Winiwarter, W., and Leitão, J.: Methane release from wetlands and watercourses in Europe, Atmos. Environ., 43, 1421-1429, 2009.

Sasakawa, M., Machida, T., Tsuda, N., Arshinov, M., Davydov, D., Fofonov, A., and Krasnov, O.: Aircraft and tower measurements of $\mathrm{CO}_{2}$ concentration in the planetary boundary layer and the lower free troposphere over southern taiga in West Siberia: Longterm records from 2002 to 2011, J. Geophys. Res., 118, 94899498, 2013.

Schubert, C. J., Diem, T., and Eugster, W.: Methane Emissions from a Small Wind Shielded Lake Determined by Eddy Covariance, Flux Chambers, Anchored Funnels, and Boundary Model Calculations: A Comparison, Environ. Sci. Technol., 46, 4515-4522, 2012.

Schuur, E. A. G., McGuire, A. D., Schädel, C., Grosse, G., Harden, J. W., Hayes, D. J., Hugelius, G., Koven, C. D., Kuhry, P., Lawrence, D. M., M.Natali, S., Olefeldt, D., Romanovsky, V. E., Schaefer, K., Turetsky, M. R., Treat, C. C., and Vonk, E. J.: Climate change and the permafrost carbon feedback, Nature, 520, 171-179, 2015. 
Shindell, D. T., Faluvegi, G., Koch, D. M., Schmidt, G. A., Unger, N., and Bauer, S. E.: Improved attribution of climate forcing to emissions, Science, 326, 716-718, 2009.

Simpson, I. J., Sulbaek Andersen, M. P., Meinardi, S., Bruhwiler, L., Blake, N. J., Helmig, D., Rowland, F. S., and Blake, D. R.: Long-term decline of global atmospheric ethane concentrations and implications for methane, Nature, 488, 490-494, 2012.

Singh, K., Jardak, M., Sandu, A., Bowman, K., Lee, M., and Jones, D.: Construction of non-diagonal background error covariance matrices for global chemical data assimilation, Geosci. Model Dev., 4, 299-316, doi:10.5194/gmd-4-299-2011, 2011.

Sweeney, C., Karion, A., Wolter, S., Newberger, T., Guenther, D., Higgs, J. A., Andrews, A. E., Lang, P. M., Neff, D., Dlugokencky, E., Miller, J. B., Montzka, S. A., Miller, B. R., Masarie, K. A., Biraud, S. A., Novelli, P. C., Crotwell, M., Crotwell, A. M., Thoning, K., and Tans, P. P.: Seasonal climatology of $\mathrm{CO}_{2}$ across North America from aircraft measurements in the NOAA/ESRL Global Greenhouse Gas Reference Network, J. Geophys. Res.Atmos., 120, 5155-5190, 2015.

Tan, Z. and Zhuang, Q.: Arctic lakes are continuous methane sources to the atmosphere under warming conditions, Environ. Res. Lett., 10, 054016, doi:10.1088/1748-9326/10/5/054016, 2015a.

Tan, Z. and Zhuang, Q.: Methane emissions from pan-Arctic lakes during the 21st century: An analysis with process-based models of lake evolution and biogeochemistry, J. Geophys. Res.-Biogeo., 120, 2641-2653, 2015b.

Tan, Z., Zhuang, Q., and Walter Anthony, K.: Modeling methane emissions from arctic lakes: Model development and site-level study, J. Adv. Model. Earth Syst., 7, 459-483, 2015.

Tarnocai, C., Canadell, J. G., Schuur, E. A. G., Kuhry, P., Mazhitova, G., and Zimov, S.: Soil organic carbon pools in the northern circumpolar permafrost region, Global Biogeochem. Cy., 23, GB2023, doi:10.1029/2008GB003327, 2009.

Thompson, R. L., Stohl, A., Zhou, L. X., Dlugokencky, E., Fukuyama, Y., Tohjima, Y., Kim, S.-Y., Lee, H., Nisbet, E. G., Fisher, R. E., Lowry, D., Weiss, R. F., Prinn, R. G., O’Doherty, S., Young, D., and White, J. W. C.: Methane emissions in East Asia for 2000-2011 estimated using atmospheric Bayesian inversion, J. Geophys. Res. Atmos., 120, 4352-4369, 2015.

Thornton, B. F., Geibel, M. C., Crill, P. M., Humborg, C., and Mörth, C.-M.: Methane fluxes from the sea to the atmosphere across the Siberian shelf seas, Geophys. Res. Lett., 43, 58695877, 2016.

Turner, A. J., Jacob, D. J., Wecht, K. J., Maasakkers, J. D., Biraud, S. C., Boesch, H., Bowman, K. W., Deutscher, N. M., Dubey, M. K., Griffith, D. W. T., Hase, F., Kuze, A., Notholt, J., Ohyama, H., Parker, R., Payne, V. H., Sussmann, R., Velazco, V. A., Warneke, T., Wennberg, P. O., and Wunch, D.: Estimating global and North American methane emissions with high spatial resolution using GOSAT satellite data, Atmos. Chem. Phys., 15, 7049-7069, doi:10.5194/acp-15-7049-2015, 2015. van der Werf, G. R., Randerson, J. T., Giglio, L., Collatz, G. J., Mu, M., Kasibhatla, P. S., Morton, D. C., DeFries, R. S., Jin, Y., and van Leeuwen, T. T.: Global fire emissions and the contribution of deforestation, savanna, forest, agricultural, and peat fires (19972009), Atmos. Chem. Phys., 10, 11707-11735, doi:10.5194/acp10-11707-2010, 2010.

Walter, K. M., Zimov, S. A., Chanton, J. P., Verbyla, D., and Chapin III, F. S.: Methane bubbling from Siberian thaw lakes as a positive feedback to climate warming, Nature, 443, 71-75, 2006.

Walter, K. M., Smith, L. C., and Chapin III, F. S.: Methane bubbling from northern lakes: present and future contributions to the global methane budget, P. T. Roy. Soc. A, 365, 1657-1676, 2007.

Wang, J. S., Logan, J. L., McElroy, M. B., Duncan, B. N., Megretskaia, I. A., and Yantosca, R. M.: 3-D model analysis of the slowdown and interannual variability in the methane growth rate from 1988 to 1997, Global Biogeochem. Cy., 18, GB3011, doi:10.1029/2003GB002180, 2004.

Wania, R., Melton, J. R., Hodson, E. L., Poulter, B., Ringeval, B., Spahni, R., Bohn, T., Avis, C. A., Chen, G., Eliseev, A. V., Hopcroft, P. O., Riley, W. J., Subin, Z. M., Tian, H., van Bodegom, P. M., Kleinen, T., Yu, Z. C., Singarayer, J. S., Zürcher, S., Lettenmaier, D. P., Beerling, D. J., Denisov, S. N., Prigent, C., Papa, F., and Kaplan, J. O.: Present state of global wetland extent and wetland methane modelling: methodology of a model inter-comparison project (WETCHIMP), Geosci. Model Dev., 6, 617-641, doi:10.5194/gmd-6-617-2013, 2013.

Wecht, K. J., Jacob, D. J., Frankenberg, C., Jiang, Z., and Blake, D. R.: Mapping of North American methane emissions with high spatial resolution by inversion of SCIAMACHY satellite data, J. Geophys. Res. Atmos., 119, 7741-7756, 2014.

Zhu, X., Zhuang, Q., Qin, Z., Glagolev, M., and Song, L.: Estimating wetland methane emissions from the northern high latitudes from 1990 to 2009 using artificial neural networks, Global Biogeochem. Cy., 27, 592-604, 2013.

Zhuang, Q., Melillo, J. M., Kicklighter, D. W., Prinn, R. G., McGuire, A. D., Steudler, P. A., Felzer, B. S., and Hu, S.: Methane fluxes between terrestrial ecosystems and the atmosphere at northern high latitudes during the past century: A retrospective analysis with a process-based biogeochemistry model, Global Biogeochem. Cy., 18, GB3010, doi:10.1029/2004GB002239, 2004.

Zhuang, Q., Melillo, J. M., Sarofim, M. C., Kicklighter, D. W., McGuire, a. D., Felzer, B. S., Sokolov, A., Prinn, R. G., Steudler, P. A., and $\mathrm{Hu}, \mathrm{S}$.: $\mathrm{CO}_{2}$ and $\mathrm{CH}_{4}$ exchanges between land ecosystems and the atmosphere in northern high latitudes over the 21st century, Geophys. Res. Lett., 33, L17403, doi:10.1029/2006GL026972, 2006.

Zhuang, Q., Melillo, J. M., McGuire, A. D., Kicklighter, D. W., Prinn, R. G., Steudler, P. A., Felzer, B. S., and Hu, S.: Net emissions of $\mathrm{CH}_{4}$ and $\mathrm{CO}_{2}$ in Alaska: Implications for the region's greenhouse gas budget, Ecol. Appl., 17, 203-212, 2007. 